\title{
Araxá, 1816-1888: Posse de Escravos, Atividades Produtivas, Riqueza
}

\author{
Déborah Oliveira Martins dos Reis \\ Professora C.C.S.A/Mackenzie \\ Endereço: Rua da Consolação, 930, Prédio T - São Paulo - Brasil - CEP: 01302-907 \\ E-mail: dreis@usp.br \\ Recebido em 19 de novembro de 2012. Aceito em 17 de fevereiro de 2014.
}

\section{Resumo}

Através do recurso aos inventários post-mortem e a documentação de caráter censitário, o trabalho detém-se sobre algumas características demográficas, ocupacionais e de acúmulo de riqueza encontradas para os araxaenses - principalmente aqueles ligados à escravidão - no período 1816-1888. A economia de subsistência preponderante em Araxá foi a base para o povoamento incipiente de suas terras em fins dos Setecentos, bastante ampliado no século XIX, de acordo com dados censitários apresentados. Aos cabedais mais modestos encontrados inicialmente juntaram-se outros de maior monta, apontando para o aumento do nível da riqueza acumulada na localidade e para variações na sua concentração - ainda que o setor agrícola fosse predominante em todo o período estudado. Riqueza e atividades produtivas estavam intimamente ligadas à posse de cativos, encontrada, em geral, na forma de pequenos e médios plantéis.

\section{Palavras-Chave}

estrutura da posse de escravos, demografia escrava, economia da escravidão, distribuição da riqueza

\begin{abstract}
This work is based on inventories and manuscript censuses (1831-32 e 1873) and focuses demographic elements, occupational structure and resources levels of the Araxá population - especially the slaveholders - between 1816 and 1888. In Araxá, the economy, distinguished through the cattle raising activity and agricultural production for domestic consumption, was capable of population increase maintenance in the XIX century, according to the presented censuses data. Bigger resources had been joined to the modest resources found initially, pointing to resources levels variations in the community and to variations on its concentration. We may say that resources and occupational structure presented some kind of relation to the size of the slaveholding.
\end{abstract}

\section{Keywords}

slaveholding, slave demography, slavery economy, wealth distribution

\section{JEL Classification}

N36

- A autora agradece os comentários recebidos do Prof. José Flávio Motta e dos dois parecerista da Estudos Econômicos, assim como à Fapesp pelo aporte financeiro à pesquisa. 


\section{Introdução}

Fundada ao final do século XVIII, ao longo dos caminhos utilizados por expedições colonizadoras em busca de ouro, Araxá foi um dos primeiros núcleos de povoamento da região de Minas Gerais atualmente compreendida pelo Triângulo Mineiro e o Alto Paranaíba áreas que naquele momento inicial pertenciam a Goiás, sendo incorporadas pela capitania, depois província, mineira em 1816. A freguesia de São Domingos do Araxá foi criada em 1791, passou a julgado em 1811, sendo elevada a vila em outubro de 1831. No ano de 1865, recebeu o título de cidade. ${ }^{l}$

Desde os primórdios do seu povoamento, a localidade manteve imutável, como base de sua economia, a agropecuária de subsistência, por vezes intensificando-se sua faceta mercantil. As vantagens de suas águas salobras, somadas à demanda de alimentos gerada pelo Rio de Janeiro (principalmente a partir de 1808), fizeram da pecuária a mais relevante das atividades econômicas locais, geradora de importantes divisas, apesar da presença constante de intermediários na comercialização de seus rebanhos.

Conjuntamente com a pecuária, a produção de víveres - milho, feijão, arroz, cana, mandioca, café, entre outros - compôs o cenário produtivo local, marcado pela diversificação, que implicou a possibilidade de autossuficiência com relação a vários produtos da terra e consequente comercialização do excedente gerado. Frutos dessa agropecuária (produção de algodão e criação de ovinos) expandiam-se também para a confecção de tecidos de lã e de algodão.

O desenvolvimento dessa economia local, ao mesmo tempo voltado ao autoconsumo e ao mercado, foi capaz de fixar e sustentar o crescimento de uma considerável população, que em 1873 já atingia mais de 16.000 pessoas (entre livres e escravos). Simultaneamente, permitiu a vários de seus investidores, em boa medida concentradores da riqueza local, o acúmulo de capitais suficientes para a manutenção do trabalho escravo na localidade, de maneira ora mais ora menos vigorosa.

1 Para uma melhor visualização do território estudado ver comentários e figura dispostos no anexo 1 . 
Isso posto, nossa intenção é justamente verificar algumas das características demográficas, ocupacionais e de acúmulo de riqueza dos araxaenses, principalmente aqueles ligados à escravidão até sua extinção em 1888. De início, apresentamos um rápido apanhado da evolução da população local (em especial livre), fixando-nos posteriormente nas características demográficas dos proprietários de cativos e na distribuição de seus escravos por faixas de tamanho de plantel (FTP). Em seguida, apresentamos um perfil das atividades produtivas locais, as quais também se relacionam aos distintos tamanhos de plantel; assim como acrescemos, ao fim do trabalho, uma análise acerca do evolver dos níveis e da concentração da riqueza acumulada na localidade.

Para tanto, utilizamos a lista nominativa de habitantes de 1831-32, o Recenseamento de 1873 e um conjunto de inventários post-mortem locais. Para os inventários estabelecemos um corte temporal que privilegia os segundos lustros de cada década entre 1816 (ano em que a localidade foi incorporada a Minas Gerais) até 1888 (término do sistema escravista brasileiro). Foi selecionada a quantidade de inventários seguinte: 1816-1820 (23 documentos), 1826-1829 (37), 1836-1839 (20), 1846-1848 (38), 1856-1858 (41), 1866-1868 (61), 1876-1878 (53), 1886-1888 (58), correspondente ao total de inventários existentes para a localidade nesses anos (subperíodos). ${ }^{2}$

\section{População, Escravistas e Posse de Escravos}

De acordo com os dados da lista nominativa de 1831-32, ${ }^{3}$ existiam em Araxá naqueles anos 4.266 habitantes, entre livres e escravos. Os cativos representavam $30,8 \%$ da população araxaense e estavam espalhados por $252(37,6 \%)$ dos 671 fogos listados, percentual considerável, superior ao valor calculado para a província como um todo nesse mesmo momento, 32,5\% (cf. Paiva, 1996, p.214).

2 Embora o Recenseamento Geral do Império tenha sido realizado em grande parte do território brasileiro em 1872, em Minas Gerais o referido censo só foi feito em 1873; optamos, então, por adotar em nosso trabalho, como referência, o ano de 1873.

3 As listas nominativas utilizadas para o levantamento populacional são referentes ao "Distrito Paroquial de São Domingos do Araxá" (1832) e ao "Distrito da Capela de São Pedro de Alcântara, Termo do Araxá" (1831), da Comarca da Vila de Paracatu do Príncipe. 
De acordo com os dados censitários, o contingente livre araxaense apresentou uma razão de sexo igual a 102,3, demonstrando um equilíbrio entre os sexos típico de populações livres. Essa razão aumentava para 149,2 , entre os cativos.

Os livres eram majoritariamente brancos $(55,3 \%)$, sendo considerável o percentual representado pelos pardos, $40 \%$. Brancos eram predominantes também na população total, 38,3\%. Esses valores eram bastante próximos para homens e mulheres observados separadamente, no total da população e entre os livres. A maior parte dos livres com estado conjugal declarado era composta por casados, $54,9 \%(56,1 \%$ dos homens e 53,9\% das mulheres).

No que respeita às idades do total da população livre em 1831-32, encontramos uma grande quantidade de crianças ( 0 a 14 anos) e jovens (15 a 24 anos) e baixa porcentagem de pessoas com idade mais avançada, principalmente acima dos 55 anos: ${ }^{4}$ cerca de $15,5 \%$ dos livres araxaenses tinham até 4 anos, enquanto os maiores de 64 anos eram apenas $1,6 \%$ da população.

Poucos anos depois, alguns quadros impressos de um documento datado de janeiro de 1834, denominado Censo da Província de Minas Gerais, bem mais simples que a lista nominativa, apontavam a existência de 6.243 habitantes, sendo 4.265 livres $(68,3 \%){ }^{5}$ Os livres tinham razão de sexo igual a 99 e eram em sua maioria brancos $(48,4 \%)$ e solteiros $(67,5 \%)$. Por outro lado, os escravos eram proporcionalmente mais homens $(60,8 \%)$, pretos $(91,8 \%)$ e solteiros $(85,7 \%)$.

De acordo com Raimundo Matos, na Corografia histórica da província de Minas Gerais (1979), o distrito próprio de Araxá possuía, em 1837, 114 fogos e 672 almas. Já o total do julgado de Araxá possuía 1.237 fogos e 6.510 almas. O Almanaque administrativo, civil e industrial da Província de Minas Gerais (1864, p.69) registrou, para o ano de 1862, 16.656 habitantes no município de Araxá, incluindo os

4 Para uma discussão acerca dos escravos considerados velhos ver, entre outros, Motta (2008); ainda que o autor aponte como 50 anos a idade indicada para definir um escravo como velho, adotamos a idade de 55 anos devido à forma como as idades foram arroladas no documento que consultamos.

5 Nesse caso são considerados o distrito próprio da vila de Araxá e os distritos de São Pedro de Alcântara (Ibiá) e Nossa Senhora da Conceição (Perdizes). 
distritos de Nossa Senhora da Conceição, São Pedro de Alcântara, Dores de Santa Juliana, Pratinha e São Jerônimo das Poções.

O primeiro censo da nova cidade (criada em 1865) foi o Recenseamento Geral do Império em 1873, quando foi anotada a existência de 16.345 habitantes, sendo $20,9 \%$ escravos. ${ }^{6} \mathrm{O}$ número de homens na população total excedia o das mulheres (razão de sexo de 123,2 ), principalmente entre os cativos, $62,2 \%$ do sexo masculino. Os brancos representavam $48,2 \%$ da população local, pardos e pretos respondiam por cerca de $24 \%$ cada. A maior parte dos indivíduos era composta por solteiros, somando $77,3 \%$ (percentual determinado pelos brancos, $73,9 \%$, pois em se tratando apenas dos cativos dita cifra eleva-se a 92,1\%).

Em 1873, a população livre araxaense apresentou uma estrutura etária bem diferente daquela verificada para quatro décadas antes: população mais envelhecida. O percentual de crianças e jovens mostrou-se inferior ao percentual encontrado para as pessoas nas faixas superiores. Pouco mais de $31 \%$ dos araxaenses tinham até 20 anos, enquanto outros $57 \%$ tinham entre 21 e 50 anos de idade. ${ }^{7}$

Poucos anos depois, em 1878, Silva, em seu Tratado de Geographia Descriptiva da Província de Minas Gerais afirmou ter o município de Araxá 16.194 almas, entrando nesse número três mil almas da população da cidade. Tinha um comando superior de guardas nacionais e um colégio eleitoral composto de 40 eleitores.

Esse valor inclui a paróquia de Araxá e da Pratinha.

Devemos ser cautelosos nas observações sobre idade de acordo com este documento, pois, como bem demonstraram Paiva e Martins (1983), em estudo crítico sobre este recenseamento, havia incorreções na estrutura etária arrolada. No entanto, é possível que esta estrutura etária tenha refletido movimentos migratórios em direção a Araxá, que se apresentava como alternativa econômica possível, para as populações de outras regióes. Para 1831-32, Paiva já apontava Araxá como uma região com forte movimento colonizador, e a receber população (cf. Paiva, 1996, p.91 e p.147). E para Waldemar Barbosa, uma prova de que Araxá continuou a atrair pessoas de outras localidades está na relação de seus voluntários da Pátria (1865): "Nessa relação, vamos encontrar moços de Dores do Indaiá, Bagagem, Uberaba, Formiga, Pitangui, Bambuí, São Francisco das Chagas, S. Pedro da Uberabinha, Baependi, Sacramento, Santo Antonio dos Tiros, Patrocínio, Arcos, Catalão, Rio de Janeiro, São Paulo, Bahia; mas a maioria era mesmo nascida em Araxá. " (Barbosa, 1995, p.34) 
Tabela 1 - População livre de acordo com o sexo: total, chefes de fogo e escravistas (1831-1832)

\begin{tabular}{|c|c|c|c|c|}
\hline & Sexo & $\%(№)$ & & Razão de sexo \\
\hline & Homens & $50,6(1492)$ & & 102,3 \\
\hline \multirow[t]{3}{*}{ População livre* } & Mulheres & $49,4(1458)$ & & \\
\hline & Homens + Mulheres & $100(2950)$ & & \\
\hline & Homens & $81,2(545)$ & & 432,5 \\
\hline \multirow[t]{3}{*}{ Chefes de fogo } & Mulheres & $18,8(126)$ & & \\
\hline & Homens + Mulheres & $100(671)$ & & \\
\hline & Homens & $79,4(200)$ & & 384,6 \\
\hline \multirow[t]{2}{*}{ Escravistas } & Mulheres & $20,6(52)$ & & \\
\hline & Homens + Mulheres & $100(252)$ & & \\
\hline \multicolumn{2}{|c|}{ \% Escravistas entre a população total } & \multicolumn{3}{|c|}{8,5} \\
\hline \multicolumn{2}{|c|}{$\%$ Escravistas entre os chefes de fogo } & \multicolumn{3}{|c|}{37,6} \\
\hline \multicolumn{2}{|c|}{$\%$ homens escravistas entre os homens } & \multicolumn{3}{|c|}{13,4} \\
\hline \multicolumn{2}{|c|}{$\%$ Mulheres escravistas entre as mulheres } & \multicolumn{3}{|c|}{3,6} \\
\hline \multicolumn{2}{|c|}{$\%$ homens escravistas entre os homens chefes de fogo } & \multicolumn{3}{|c|}{36,7} \\
\hline \multicolumn{2}{|c|}{$\%$ Mulheres escravistas entre as mulheres chefes de fogo } & \multicolumn{3}{|c|}{42,3} \\
\hline
\end{tabular}

A Tabela 1 mostra a população livre total e também chefes de fogo e proprietários de cativos segmentados por sexo, a partir dos informes contidos na lista nominativa. ${ }^{8}$ De acordo com o levantamento realizado, a razão de sexo de 102,3 do contingente livre total era multiplicada por mais de quatro quando consideramos apenas os chefes de fogo $(432,5)$, mantendo-se bastante elevada $(384,6)$ entre os chefes das unidades domiciliares com escravos, 79,4\% homens, ou seja, era essencialmente masculina a parcela da população possuidora de cativos. Mas, devemos ser cautelosos e sopesar nossas observações, pois, como mencionado anteriormente, grande parcela da população era casada, aparecendo sempre, nesse caso, o cônjuge do sexo masculino como chefe de fogo e consequentemente como o proprietário de cativos.

\footnotetext{
8 Todos os indivíduos considerados escravistas são chefes de domicílio, ou seja, denominamos escravistas aqueles araxaenses chefes de fogos onde foram localizados cativos.
} 
Os valores encontrados, atestando uma grande maioria de escravistas homens, repetiam-se em outras regióes brasileiras, em maior ou menor intensidade, como têm demonstrado diversos trabalhos sobre estrutura da posse de cativos. Valor praticamente coincidente com o nosso número para Araxá foi apresentado, por exemplo, por Luna (1998). As listas nominativas de 25 localidades paulistas, divididas em cinco regiões, estudadas pelo autor para o período 1777-1829 apontaram um percentual de cerca de $80 \%$ de escravistas do sexo masculino, "situação verificada sem alterações importantes no tempo e no espaço". (Luna, 1998, p.112)

Quando relacionamos os escravistas com a população livre total e os chefes de fogo, notamos que o peso dos homens proprietários de escravos, no conjunto dos homens livres, mostrava-se bastante superior ao mesmo indicador calculado para as mulheres. No primeiro caso, o percentual alçava-se a $13,4 \%$, enquanto no segundo era de apenas 3,6\%. Eliminando as crianças (0-14 anos), 1.324 indivíduos no total, os percentuais seriam de $24,4 \%$ para os homens e $6,4 \%$ para as mulheres. Considerando apenas os chefes de fogo, $42,3 \%$ das mulheres eram escravistas contra 36,7\% dos homens.

Tabela 2 - Estrutura etária dos escravistas por sexo (1831-1832)

\begin{tabular}{cccc}
\hline Faixa Etária (anos) & $\begin{array}{c}\text { Homens } \\
\%\end{array}$ & $\begin{array}{c}\text { Mulheres } \\
\%\end{array}$ & $\begin{array}{c}\text { Homens }+ \\
\text { Mulheres \% }\end{array}$ \\
\hline 5 a 9 & - & - & - \\
10 a 14 & - & - & - \\
15 a 19 & 1,5 & - & 1,2 \\
20 a 24 & 7,9 & 5,8 & 7,5 \\
25 a 29 & 18,0 & 5,8 & 15,5 \\
30 a 34 & 13,0 & 17,3 & 13,9 \\
35 a 39 & 13,5 & 1,9 & 11,1 \\
40 a 44 & 11,0 & 7,7 & 10,3 \\
45 a 49 & 7,9 & 13,5 & 9,1 \\
50 a 54 & 10,0 & 17,3 & 11,5 \\
55 a 59 & 7,6 & 9,6 & 7,9 \\
60 a 64 & 6,1 & 5,8 & 6,0 \\
65 a 69 & 1,5 & 3,8 & 2,0 \\
70 acima & 2,0 & 11,5 & 4,0 \\
\hline Total & 100,0 & 100,0 & 100,0 \\
\hline
\end{tabular}

Fonte: APM, Lista Nominativa de Habitantes de Araxá, 1831-1832 
Os senhores de escravos possuíam idade mínima na faixa dos 15 aos 19 anos, conforme exposto na Tabela 2. Colocavam-se entre 25 e 39 anos as faixas com percentuais mais elevados para os homens, a partir de $13 \%$ cada uma, com destaque para aqueles com 25-29 anos (18\%), totalizando $44,5 \%$ dos chefes de fogo homens com cativos, percentual que reduz-se a $40,5 \%$ se consideramos também as mulheres. Para os dois sexos conjuntamente, são importantes também os percentuais calculados para as 3 faixas seguintes, onde se concentrava a maioria feminina, que chegou a $17,3 \%$ na faixa dos 50 aos 54 anos de idade.

Relativamente ao estado conjugal (Tabela 3), identificamos em Araxá, para homens mais mulheres escravistas uma maioria de casados, 71,6\%. Enquanto entre os homens 85,9\% eram casados, mais da metade das mulheres haviam conhecido o casamento, porém, já eram viúvas. Este aspecto certamente tem influência no valor calculado para a relação entre mulheres escravistas e mulheres chefes de fogo apresentado anteriormente.

Fato é que as mulheres assumiam a condição de chefiar seu núcleo doméstico mormente, quando viúvas. O que não ocorria com os homens, que em sua maioria eram casados ao apresentarem-se como chefes de fogo, com percentuais bem mais elevados que aqueles verificados para o total da população livre masculina. Assim, justifica-se o fato de que as mulheres casadas eram parcela menos representativa entre todas aquelas que possuíam cativos. Provavelmente, apareceriam como escravistas casadas aquelas cujos maridos estavam envolvidos em atividades que implicassem longas viagens ou serviços militares. Ademais, é sabido que o desequilíbrio entre os sexos favorecia os homens no "mercado matrimonial" e, em maiores proporções que indivíduos do sexo masculino, mulheres tendiam a permanecer na condição de viúvas. ${ }^{9}$

9 "Os homens tinham maiores dificuldades de se manterem sós, sem companheiras, e procuravam, pois, buscar logo o casamento [...] As viúvas encontravam maiores dificuldades para encontrar um segundo marido. Muito poucos eram os solteiros que se dispunham a casar-se com elas. Preconceito social mas também pressão de uma sociedade em que as moças em idades casadouras eram sempre em maior número do que os rapazes. Por isso, a comunidade não podia permitir, com facilidade, a concorrência aos jovens solteiros que as viúvas pudessem lhes fazer." (Marcílio, 2006, p.175) Ver também, entre outros, Teixeira (2004), Bacellar (2001) 
Tabela 3 - Estado conjugal dos escravistas por sexo (1831-1832)

\begin{tabular}{lccc}
\hline \multicolumn{1}{c}{$\begin{array}{c}\text { Estado } \\
\text { Conjugal }\end{array}$} & $\begin{array}{c}\text { Homens }^{*} \\
\%\end{array}$ & $\begin{array}{c}\text { Mulheres } \\
\%\end{array}$ & $\begin{array}{c}\text { Homens }^{*}+ \\
\text { Mulheres \% }\end{array}$ \\
\hline \hline Solteiros & 9,6 & 28,8 & 13,6 \\
Casados & 85,9 & 17,3 & 71,6 \\
Viúvos & 4,5 & 53,8 & 14,8 \\
\hline Total & 100,0 & 100,0 & 100,0 \\
\hline
\end{tabular}

* Exclusive 1 homem que não teve o estado conjugal informado Fonte: APM, Lista Nominativa de Habitantes de Araxá, 1831-1832

Utilizando os inventários post-mortem não foi possível identificar as características demográficas dos componentes da nossa amostra, tampouco dos escravistas inventariados, como fizemos para aqueles indivíduos que compõem a documentação censitária de 1831-32. No entanto, observamos a grande importância assumida pelos escravos na presença maciça de escravistas e escravos nos arrolamentos consultados. Nos 249 inventários de escravistas relativos a 1816-1888, encontramos 1886 escravos. Em 1816-1848, 83\% dos documentos faziam menção a cativos; já na segunda metade do século XIX esse percentual girava em torno de $70 \%$. Importante notarmos, dada a participação de inventários escravistas por subperíodos, que durante a primeira metade dos Oitocentos não menos de 76,3\% (valor encontrado para 1846-48) dos processos descreviam escravos e, a partir de 1866-1868, esse percentual passou por gradual queda, acompanhando as mudanças ocorridas no sistema escravista brasileiro. ${ }^{10}$

Colocadas essas observações sobre os escravistas araxaenses, passemos a analisar como a posse de cativos se distribuía entre esses proprietários entre 1816-1820 e 1886-1888 e em 1831-32. A Tabela 4 mostra o padrão de distribuição de escravos e senhores de acordo com faixas de tamanho dos plantéis. Ao verificar o peso dos segmentos de plantéis pequenos (considerados aqueles plantéis com a 1 a 5 cativos), médios (6 a 10), grandes (11 a 20) e muito grandes (acima de 20), percebemos o predomínio, na Araxá Oitocentista, de um escravismo de pequenos e médios proprietários.

\footnotetext{
${ }^{10}$ A grande disparidade com relação ao percentual calculado de acordo com os dados da lista nominativa - em 1826-29, subperíodo mais próximo a 1831-32, 81,1\% dos inventariados eram escravistas, enquanto na lista nominativa $37,6 \%$ dos chefes de fogo estavam nesta condição deve-se à menor abrangência dos inventários em função do seu caráter específico. Decerto, havia em Araxá um grupo de indivíduos não escravistas, tampouco possuidores de outros bens inventariáveis, não abarcados nesses documentos utilizados. Todavia, esse ponto não invalida a análise proposta, pois parece-nos razoável pensar que os inventários conformam uma boa amostra para aqueles proprietários de um mínimo de bens, sendo relevante a posse de cativos.
} 
Verificamos a presença majoritária de pequenos plantéis (até 5 cativos) para a totalidade dos anos observados. No entanto, a distribuição mostra uma mudança significativa durante as décadas. Passouse, segundo os dados apresentados, de $68,4 \%$ de plantéis de até 5 escravos, nos anos 1816-1820, para cerca de 50\%, entre 1836-39 e 1856-58. Talvez seja razoável pensar que, com o passar do tempo, houve consolidação da economia escravista local, levando a um incremento da presença de plantéis de maior vulto em detrimento dos pequenos plantéis. Em 1846-48, por exemplo, é marcante a presença de proprietários com escravarias de tamanho médio (6 a 10 escravos), $27,6 \%$. No entanto, nas décadas finais da escravidão basicamente plantéis de até 10 escravos foram encontrados; nos anos 1886-88 mais de 90\% dos plantéis arrolados estavam nessa situação. Mas devemos ser cautelosos em nossas observações, dada a fonte utilizada e, é claro, tendo em mente que o quadro mostrado pelos inventários, em determinado momento, representa processos ocorridos anteriormente.

Tabela 4 - Distribuição de escravistas e de escravos de acordo com faixas de tamanho dos plantéis (1816-1820 a 1886-1888; 1831-1832)

\begin{tabular}{|c|c|c|c|c|c|c|c|c|c|c|c|c|}
\hline \multirow{3}{*}{ FTP } & \multicolumn{4}{|c|}{$1816-1820$} & \multicolumn{4}{|c|}{$1826-1829$} & \multicolumn{4}{|c|}{$1836-1839$} \\
\hline & \multicolumn{2}{|c|}{ Escravistas } & \multicolumn{2}{|c|}{ Escravos } & \multicolumn{2}{|c|}{ Escravistas } & \multicolumn{2}{|c|}{ Escravos } & \multicolumn{2}{|c|}{ Escravistas } & \multicolumn{2}{|c|}{ Escravos } \\
\hline & № & $\%$ & № & $\%$ & № & $\%$ & № & $\%$ & № & $\%$ & № & $\%$ \\
\hline 1 a 5 & 13 & 68,4 & 32 & 29,9 & 20 & 66,7 & 44 & 32,1 & 10 & 50,0 & 20 & 8,4 \\
\hline 6 a 10 & 4 & 21,1 & 28 & 26,2 & 5 & 16,7 & 55 & 19,2 & 3 & 15,0 & 23 & 9,7 \\
\hline 11 a 20 & 1 & 5,3 & 14 & 13,1 & 3 & 10,0 & 42 & 21,8 & 3 & 15,0 & 44 & 18,6 \\
\hline Acima 20 & 1 & 5,3 & 33 & 30,8 & 2 & 6,7 & 52 & 26,9 & 4 & 20,0 & 150 & 63,3 \\
\hline \multirow[t]{2}{*}{ Total } & 19 & 100,0 & 107 & 100,0 & 30 & 100,0 & 193 & 100,0 & 20 & 100,0 & 237 & 100,0 \\
\hline & \multicolumn{4}{|c|}{$1846-1848$} & \multicolumn{4}{|c|}{$1856-1858$} & \multicolumn{4}{|c|}{$1866-1868$} \\
\hline \multirow[t]{2}{*}{ FTP } & \multicolumn{2}{|c|}{ Escravistas } & \multicolumn{2}{|c|}{ Escravos } & \multicolumn{2}{|c|}{ Escravistas } & \multicolumn{2}{|c|}{ Escravos } & \multicolumn{2}{|c|}{ Escravistas } & \multicolumn{2}{|c|}{ Escravos } \\
\hline & № & $\%$ & № & $\%$ & № & $\%$ & № & $\%$ & № & $\%$ & № & $\%$ \\
\hline 1 a 5 & 16 & 55,2 & 51 & 22,9 & 18 & 50,0 & 52 & 15,4 & 21 & 43,8 & 57 & 12,1 \\
\hline 6 a 10 & 8 & 27,6 & 61 & 27,4 & 7 & 19,4 & 55 & 16,3 & 15 & 31,3 & 116 & 24,6 \\
\hline 11 a 20 & 2 & 6,9 & 27 & 12,1 & 7 & 19,4 & 106 & 31,5 & 5 & 10,4 & 69 & 14,6 \\
\hline Acima 20 & 3 & 10,3 & 84 & 37,7 & 4 & 11,1 & 124 & 36,8 & 7 & 14,6 & 229 & 48,6 \\
\hline \multirow[t]{2}{*}{ Total } & 29 & 100,0 & 223 & 100,0 & 36 & 100,0 & 337 & 100,0 & 48 & 100,0 & 471 & 100,0 \\
\hline & \multicolumn{4}{|c|}{$1876-1878$} & \multicolumn{4}{|c|}{$1886-1888$} & \multicolumn{4}{|c|}{$1831-1832$} \\
\hline \multirow[t]{2}{*}{ FTP } & \multicolumn{2}{|c|}{ Escravistas } & \multicolumn{2}{|c|}{ Escravos } & \multicolumn{2}{|c|}{ Escravistas } & \multicolumn{2}{|c|}{ Escravos } & \multicolumn{2}{|c|}{ Escravistas } & & \\
\hline & № & $\%$ & № & $\%$ & № & $\%$ & № & $\%$ & № & $\%$ & № & $\%$ \\
\hline 1 a 5 & 25 & 69,4 & 67 & 40,1 & 24 & 77,4 & 47 & 31,1 & 177 & 70,2 & 405 & 30,8 \\
\hline 6 a 10 & 9 & 25,0 & 72 & 43,1 & 4 & 12,9 & 29 & 19,2 & 44 & 17,5 & 336 & 25,5 \\
\hline 11 a 20 & 2 & 5,6 & 28 & 16,8 & 1 & 3,2 & 13 & 8,6 & 23 & 9,1 & 300 & 22,8 \\
\hline Acima 20 & - & - & - & - & 2 & 6,5 & 62 & 41,1 & 8 & 3,2 & 275 & 20,9 \\
\hline Total & 36 & 100,0 & 167 & 100,0 & 31 & 100,0 & 151 & 100,0 & 252 & 100,0 & 1316 & 100,0 \\
\hline
\end{tabular}

Fontes: APM, Lista Nominativa de Habitantes de Araxá, 1831-1832. FCCB, inventários postmortem de Araxá, anos selecionados

Por sua vez, os cativos inventariados estavam em grande proporção vivendo em pequenos e médios plantéis. $\mathrm{Na}$ primeira metade do século, à exceção de 1836-39 - em que 63,3\% dos escravos estavam 
em plantéis considerados muito grandes, em grande medida devido ao fato de um único inventário trazer entre os bens descritos 78 escravos (Inventário de José Joaquim Ribeiro e Francisca Benedita de Assis. 13/11/1837 - Arquivo FCCB, cx.34), representando 33,3\% do total dos cativos arrolados nesses anos - não menos de $50 \%$ dos cativos estavam em pequenas e médias posses consideradas conjuntamente. Em 1856-58 e 1866-68 esse percentual é menor, não deixando de ser considerável: respectivamente, 31,7\% e 36,7\%.

Em 1831-32, cerca de 70\% dos escravistas araxaenses arrolados possuíam um máximo de 5 escravos, respondendo por 30,8\% dos cativos. Na FTP seguinte, 6 a 10 escravos, encontramos 44 indivíduos, representando $17,5 \%$ dos senhores e $25,5 \%$ dos cativos, percentual pouco superior aos $22,8 \%$ de escravos possuídos por 23 araxaenses $(9,1 \%)$ com plantéis de porte grande. Apenas 8 plantéis muito grandes foram localizados, porém detinham um quinto da escravaria local.

As constatações feitas acerca da estrutura da posse de cativos em Araxá estão próximas às verificadas para várias regiões por diferentes autores, ou seja, era em grande medida semelhante, no que respeita à predominância de pequenos plantéis, à distribuição encontrada em outras localidades. Os estudos empíricos sobre o tema têm apontado para uma predominância numérica de proprietários de pequenos plantéis entre o total de senhores e para uma posse difundida para além da plantation, em economias regionais voltadas para a produção de subsistência, como ocorre em Araxá.

Enfim se, como sabido, panos de fundo socioeconômicos distintos podem dar suporte a populações cujas estruturas demográficas apresentam perfis estatísticos em boa medida semelhantes, este é o caso do padrão de distribuição da propriedade escrava no Brasil dos séculos XVIII e XIX. Nesse padrão figuravam, de forma inequívoca, vale a pena repisar, como escravista majoritário, o que possuía poucos cativos, e, como escravo típico, o que vivia fora do ambiente característico da plantation. Estes os traços delineadores da estrutura da posse de escravos mais saliente do escravismo brasileiro. (Motta, Nozoe \& Costa, 2004, pp.209-210) 
Apesar desse padrão geral básico válido para o Brasil, havia diferenças suscitadas por distintos perfis econômicos. De fato, procedendo à comparação entre alguns elementos da estrutura da posse de escravos apresentados para Araxá e os verificados por diferentes autores para outras localidades, constatamos variações (Tabela 5). ${ }^{11} \mathrm{Com}$ relação à proporção de pequenos plantéis, observamos uma grande diferença entre os valores araxaenses e os calculados, por exemplo, por Marcondes (1998) para Lorena em 1851-1879, onde a cafeicultura tendia a tornar menos expressivos os pequenos proprietários.

Ao contrário, os números apurados para Araxá mostraram-se bastante próximos aos verificados para outras localidades cujas semelhanças entre as atividades econômicas desenvolvidas eram maiores. Esse é o caso de Pernambuco, onde as atividades no agreste eram diversificadas - algodão, lavoura de alimentos e gado - e no sertão, mais voltadas à criação. No sertão, o percentual de pequenos plantéis manteve-se em $52,7 \%$, enquanto no agreste este valor alçou-se a $54,8 \%$. Como verificamos anteriormente, $58,3 \%$ dos escravistas araxaenses em 1856-1888 tinham até 5 cativos.

Tabela 5 - Média de escravos e percentual de escravistas e de escravos em pequenos plantéis em diferentes localidades (Séculos XVIII e XIX)

\begin{tabular}{lccc}
\hline \multicolumn{1}{c}{ Localidade, data } & Média & $\begin{array}{c}\text { \% Pequenos } \\
\text { plantéis }\end{array}$ & $\begin{array}{c}\% \\
\text { Escravos }\end{array}$ \\
\hline \hline & Minas Gerais & & 13,7 \\
\hline Mariana (MG), 1850-88 & 9,6 & 50,6 & 24,4 \\
Campanha (MG), 1831 & 6,3 & 65,8 & 26,6 \\
Paracatu e oeste mineiro, 1831-32 & 5,0 & 64,7 & 39,1 \\
Paracatu e oeste mineiro, 1873-75 & 3,3 & 75,4 & 11,4 \\
Livramento (MG), 1857 & - & 45,9 & 21 \\
Itabira do Campo (MG), 1831 & - & 63,2 & 16,1 \\
Itabira do Campo (MG), 1867 & - & 73,2 & 3,4 \\
\hline & Diversas localidades (inventários) & & 7,0 \\
\hline Lorena (SP), 1851-79 & 14,9 & 16,7 & 14,89 \\
Magé (RJ), 1850-56 & 13,1 & 40,0 & 18,33 \\
São Paulo (SP), 1851-60 & 10,14 & 60,0 & 18,65 \\
São Paulo (SP), 1861-70 & 8,94 & 65,12 & 16,4 \\
São Paulo (SP), 1872-81 & 8,32 & 73,33 & 21,9 \\
Agreste de Pernambuco, 1770-1887 & 5,9 & 54,8 & 52,7 \\
Sertão de Pernambuco, 1770-1887 & 5,6 & & \\
\hline
\end{tabular}

Fontes: Os dados para Mariana constam de Teixeira (2001), para Campanha constam de Paiva e Klein (1992), para Paracatu e oeste Paiva e Libby (1995), e para as demais localidades mineiras os dados foram retirados de Libby (1988). Para Lorena ver Marcondes (1998), para Magé Sampaio (1994), para São Paulo Mello (1990) e para Pernambuco Vesiani e Vergolino (2003). Os pequenos plantéis se referem àqueles com 1 a 5 escravos, à exceção de Paracatu e oeste mineiro, Lorena e Magé, cujos plantéis pequenos possuem de 1 a 4 cativos.

${ }^{11}$ Para a elaboração da tabela foram priorizadas outras localidades mineiras e localidades em outras províncias abordadas em trabalhos que lançaram mão igualmente de inventários. 


\section{Ocupações/Atividades Produtivas}

O perfil da posse de escravos verificada reflete as atividades econômicas desempenhadas pelos araxaenses. Dessa forma, longe de se destacar por grandes plantéis, a posse de cativos em Araxá foi fruto da produção de subsistência desenvolvida que teve, como não poderia ser diferente, importante papel na economia local, sendo responsável pela absorção de cativos (principalmente em pequenos plantéis), empregados quer em atividades de autossubsistência, quer em propriedades com capacidade de produzir excedentes para suprir o núcleo urbano da própria localidade ou outros mais distantes.

A lista nominativa de 1831-32 e o recenseamento de 1873 (Tabela 6) evidenciam para Araxá o grande contingente populacional ligado a atividades dos setores de agricultura e manufatura rural e artesanato. Pouco mais de $40 \%$ dos indivíduos livres com ocupação descrita em 1831-1832 foram declarados lavradores; apenas 15 pessoas (1,5\%) apareceram em atividades ligadas ao ramo da pecuária, embora, como apontado anteriormente, a pecuária tenha se firmado como a principal atividade econômica realizada. Tal constatação levou-nos a acreditar que, em geral, cultura e criação deveriam caminhar juntas. 
Tabela 6 - Distribuição das ocupações da população livre por ramos e setores de atividade econômica (1831-1832 e 1873)

\begin{tabular}{|c|c|c|c|c|}
\hline Setor & Ramo & Ocupação & $1831-32^{*}$ & $1873^{* *}$ \\
\hline \multirow{10}{*}{$\begin{array}{c}\text { Agricultura e } \\
\text { Manufatura Rural }\end{array}$} & Produção de açúcar & Engenheiro de cana & $2(0,2 \%)$ & - \\
\hline & Cultivos não especificados & Lavrador & $414(40,4 \%)$ & $3337(46,3 \%)$ \\
\hline & \multirow{3}{*}{ Pecuária } & Criador & $11(1,1 \%)$ & - \\
\hline & & Boiadeiro & $1(0,1 \%)$ & - \\
\hline & & Vaqueiro & $3(0,3 \%)$ & - \\
\hline & Pesca fluvial & Pescador & - & $1(0,0 \%)$ \\
\hline & Extrativismo vegetal & Capineiro & $1(0,1 \%)$ & \\
\hline & \multirow{2}{*}{ Outras atividades agrícolas } & Rancheiro & $1(0,1 \%)$ & \\
\hline & & Meeira & $1(0,1 \%)$ & \\
\hline & \multicolumn{2}{|c|}{ Total do setor } & $434(42,3)$ & $3338(46,4 \%)$ \\
\hline \multirow{21}{*}{ Artesanato } & \multirow{2}{*}{ Construção civil e afins } & Pedreiro & $3(0,3 \%)$ & \multirow{2}{*}{$10(0,1 \%)$} \\
\hline & & Pintor & $2(0,2 \%)$ & \\
\hline & \multirow{2}{*}{ Cerâmica e afins } & Telheiro & $9(0,9 \%)$ & - \\
\hline & & Louceiro & $1(0,1 \%)$ & - \\
\hline & \multirow{2}{*}{ Metais } & Caldereiro & $1(0,1 \%)$ & \multirow{2}{*}{$23(0,3 \%)$} \\
\hline & & Ferreiro & $10(1,0 \%)$ & \\
\hline & Madeiras & Carpinteiro ou carapina & $35(3,4 \%)$ & $41(0,6 \%)$ \\
\hline & \multirow{3}{*}{ Fiação, Tecelagem e afins } & Fiadeira & $240(23,4 \%)$ & \multirow{3}{*}{$963(13,4 \%)$} \\
\hline & & Tecedeira & $3(0,3 \%)$ & \\
\hline & & Rendeira & $8(0,8 \%)$ & \\
\hline & \multirow{2}{*}{ Couro, Peles e afins } & Curtidor & $2(0,2 \%)$ & \multirow{2}{*}{$6(0,1 \%)$} \\
\hline & & Seleiro & $9(0,9 \%)$ & \\
\hline & Calçados & Sapateiro & $31(3,0 \%)$ & $17(0,2 \%)$ \\
\hline & \multirow{3}{*}{ Vestuário } & Alfaiate & $17(1,7 \%)$ & $12(0,2 \%)$ \\
\hline & & Costureira & $65(6,3 \%)$ & $1058(14,7 \%)$ \\
\hline & & Chapeleiro & $3(0,3 \%)$ & - \\
\hline & Alimentação & Padeiro & $1(0,1 \%)$ & - \\
\hline & Jóias e afins & Ourives & $2(0,3 \%)$ & - \\
\hline & \multirow{2}{*}{ Outras atividades } & Artífice & $1(0,1 \%)$ & \multirow{2}{*}{$1(0,0 \%)$} \\
\hline & & Aprendiz & $3(0,3 \%)$ & \\
\hline & $\begin{array}{r}\text { Total do } \\
\end{array}$ & setor & $446(43,5 \%)$ & $2131(29,6 \%)$ \\
\hline \multirow{3}{*}{ Igreja } & Clero secular & & $2(0,2 \%)$ & $3(0,0 \%)$ \\
\hline & Sacristães e afins & Sacristão & $2(0,2 \%)$ & - \\
\hline & $\begin{array}{r}\text { Total do } \\
\end{array}$ & setor & $4(0,2 \%)$ & $3(0,0 \%)$ \\
\hline & Juízes & Juiz & - & $1(0,0 \%)$ \\
\hline & Tabeliães & Tabelião & $1(0,1 \%)$ & - \\
\hline Magistratura e & Escrivães, Oficiais de Justiça e & Oficial de Justiça & $5(0,5 \%)$ & $8(0,1 \%)$ \\
\hline empregos civis & afins & Escrivão & $1(0,1 \%)$ & $5(0,1 \%)$ \\
\hline & Outros serviços públicos & & $1(0,1 \%)$ & $5(0,1 \%)$ \\
\hline & Total do & setor & $8(0,8 \%)$ & $19(0,3 \%)$ \\
\hline & Advocacia e afins & Advogado & $1(0,1 \%)$ & $5(0,1 \%)$ \\
\hline & Advocacia e atıns & Agente de causas & $1(0,1 \%)$ & - \\
\hline & & Médico & - & $1(0,0 \%)$ \\
\hline & & Cirurgião & $1(0,1 \%)$ & - \\
\hline Profissões liberais & Medıcına, cirurgia e atıns & Boticário & $1(0,1 \%)$ & - \\
\hline & & Parteira & - & $3(0,0 \%)$ \\
\hline & Ensino e afins & Professor & $1(0,1 \%)$ & $4(0,1 \%)$ \\
\hline & Música & Músico & $7(0,7 \%)$ & - \\
\hline & Total do & setor & $12(1,2 \%)$ & $13(0,2 \%)$ \\
\hline & Capitalistas e proprietários & & - & $18(0,2 \%)$ \\
\hline Rentıstas & Total do & setor & - & $18(0,3 \%)$ \\
\hline & Casas de comércio e afins & Negociante & $52(5,1 \%)$ & \\
\hline & Açougues e afins & Carniceiro & $1(0,1 \%)$ & \\
\hline & Estalagens e afins & Taberneiro & $7(0,7 \%)$ & $51(0, / \%)$ \\
\hline Comercio & Serviços de caixa e afins & Caixeiro & $2(0,2 \%)$ & \\
\hline & Outras atividades de comércio & Negociante de bois & $1(0,1 \%)$ & - \\
\hline & $\begin{array}{ll}\text { Total do } \\
\end{array}$ & setor & $63(6,1 \%)$ & $51(0,7 \%)$ \\
\hline
\end{tabular}


Tabela 6 - Distribuição das ocupações da população livre por ramos e setores de atividade econômica (1831-1832 e 1873) - Continuação

\begin{tabular}{|c|c|c|c|c|}
\hline \multirow{6}{*}{ Comércio } & Casas de comércio e afins & Negociante & $52(5,1 \%)$ & \multirow{4}{*}{$51(0,7 \%)$} \\
\hline & Açougues e afins & Carniceiro & $1(0,1 \%)$ & \\
\hline & Estalagens e afins & Taberneiro & $7(0,7 \%)$ & \\
\hline & Serviços de caixa e afins & Caixeiro & $2(0,2 \%)$ & \\
\hline & Outras atividades de comércio & Negociante de bois & $1(0,1 \%)$ & - \\
\hline & Total do & & $63(6,1 \%)$ & $51(0,7 \%)$ \\
\hline \multirow{3}{*}{ Transporte } & \multirow{2}{*}{ Transporte por via terrestre } & Carreiro & $7(0,7 \%)$ & - \\
\hline & & Arrieiro & $1(0,1 \%)$ & - \\
\hline & \multicolumn{2}{|c|}{ Total do setor } & $8(0,8 \%)$ & - \\
\hline \multirow{3}{*}{ Serviços em geral } & \multirow{2}{*}{ Serviços da casa e afins } & Lavadeira & $3(0,3 \%)$ & - \\
\hline & & & - & $558(7,7 \%)$ \\
\hline & \multicolumn{2}{|c|}{ Total do setor } & $3(0,3 \%)$ & $558(7,7 \%)$ \\
\hline \multirow{3}{*}{ Jornaleiros } & Jornaleiros & Jornaleiro & $47(4,6 \%)$ & $1067(14,8 \%)$ \\
\hline & \multicolumn{2}{|c|}{ Total do setor } & $47(4,6 \%)$ & $1067(14,8 \%)$ \\
\hline & \multicolumn{2}{|c|}{ Total geral } & $1025(100,0 \%)$ & $7201(100,0 \%)$ \\
\hline \multicolumn{5}{|c|}{$\begin{array}{l}\text { Exclusive } 1931 \text { pessoas livres com ocupação não declarada (crianças e possivelmente idosos e } \\
\text { incapacitados) e } 4 \text { pessoas com ocupação múltipla. }\end{array}$} \\
\hline \multicolumn{5}{|c|}{$\begin{array}{l}\text { * Exclusive } 5728 \text { pessoas livres descritas como sem profissão (possivelmente crianças, idosos } \\
\text { e incapacitados) }\end{array}$} \\
\hline
\end{tabular}

Algumas décadas depois, em 1873, o percentual de lavradores registrado no censo foi de 46,3\%; eram mais de 3.300 pessoas livres mantendo a ocupação predominante em Araxá desde o início do povoamento do seu território.

Mostraram-se importantes também, no total de pessoas livres cujas ocupações foram identificadas, as atividades ligadas ao artesanato. Fiadeiras, tecedeiras e rendeiras eram mais de 250 (quase 25\%) em 1831-1832, chegando a quase 1.000 em 1873, embora nesse ano respondessem por $13,4 \%$ da população livre com ocupação especificada no censo, representando, dentro do setor artesanato, um percentual menor apenas que as costureiras, $14,7 \%$. Sendo essas atividades tipicamente femininas, observamos a importante participação das mulheres nas atividades produtivas araxaenses. Além desses dois setores principais, encontramos na Araxá de 1831-32 e 1873 importante participação na população dos jornaleiros, assalariados sem profissão definida, que provavelmente não conseguiam prover sua subsistência através de atividades independentes, seja no campo ou na cidade.

Apesar de empregarem reduzida parcela dos araxaenses, as atividades diretamente vinculadas à vida urbana eram diversificadas: pessoas relacionadas ao clero (necessárias para o funcionamento da localidade enquanto paróquia e presentes desde a década de 1790, 
quando foi nomeado o primeiro vigário e construída a primeira igreja Matriz de São Domingos), aquelas empregadas na magistratura, como juízes e oficiais de justiça, e os profissionais liberais (ligados ao ramo de advocacia, medicina e afins, ensino e até mesmo músicos).

Ocupadas no setor de comércio foram recenseadas 63 pessoas $(6,1 \%)$ em 1831-32 e apenas 0,7\% dos araxaenses em 1873. Pouco sabemos de específico sobre o comércio araxaense até 1830, mas encontramos nas listas de contribuintes que pagavam pela licença de seus negócios, uma relação de 21 indivíduos ligados a alguma atividade comercial no ano de 1834 (cf. Lista de um relatório para correição. 20/03/1834 Arquivo FCCB). Mais de meio século depois, em 1895, os registros de contribuintes indicavam a existência em Araxá de cerca de 40 estabelecimentos comerciais de gêneros do país, fazendas, ferragens, secos e molhados, armarinhos "e todos os demais gêneros", além de 2 farmácias, 2 botequins, 2 "mascates turcos", 1 padaria, 1 bilhar e 1 tipografia (cf. Lançamento do imposto de Industrias e Profissões do Município do Araxá no ano de 1895 - Arquivo FCCB).

A relação entre estrutura da posse de cativos e perfil econômico pode ser melhor visualizada através das atividades econômicas nas quais os escravistas (homens mais mulheres) estavam envolvidos. As ocupações declaradas na lista nominativa apresentamos nas Tabelas 7 e 8 , de acordo com as faixas de tamanho dos plantéis. ${ }^{12} \mathrm{~A}$ importância fundamental da agricultura na economia local é reforçada com os dados apresentados para as atividades principais dos fogos com cativos: percentual crescente e majoritário de participação dentro das FTP, partindo de 59,6\% entre os detentores de pequenos plantéis e chegando à totalidade de 7 araxaenses com mais de 20 escravos.

${ }^{12} \mathrm{Na}$ Tabela 7 os totais são dados com relação às FTP e na tabela seguinte soma-se $100 \%$ em cada ocupação. 
Tabela 7 - Distribuição das ocupações de escravistas por setores e ramos de atividade econômica e por faixas de tamanho dos plantéis (1831-1832)

\begin{tabular}{|c|c|c|c|c|c|c|}
\hline Setor & Ramo & Ocupação & 1 a 5 & 6 a 10 & 11 a 20 & Acima 20 \\
\hline \multirow{5}{*}{$\begin{array}{c}\text { Agricultura e } \\
\text { Manufatura Rural }\end{array}$} & Produção de açúcar & Engenheiro de cana & - & - & $1(5,0 \%)$ & - \\
\hline & Cultivos não especificados & Lavrador & $89(57,1 \%)$ & $30(75,0 \%)$ & $15(75,0 \%)$ & $6(85,7 \%)$ \\
\hline & \multirow{2}{*}{ Pecuária } & Criador & $3(1,9 \%)$ & - & - & $1(14,3 \%)$ \\
\hline & & Boiadeiro & $1(0,6 \%)$ & - & - & \\
\hline & \multicolumn{2}{|c|}{ Total do setor } & $93(59,6 \%)$ & $30(75,0 \%)$ & $16(80,0 \%)$ & $7(100,0 \%)$ \\
\hline \multirow{14}{*}{ Artesanato } & \multirow{2}{*}{ Metais } & Caldereiro & $1(0,6 \%)$ & - & - & - \\
\hline & & Ferreiro & $2(1,3 \%)$ & - & - & - \\
\hline & Madeiras & Carpinteiro ou carapina & $5(3,2 \%)$ & $2(5,0 \%)$ & $1(5,0 \%)$ & - \\
\hline & \multirow{3}{*}{ Fiação, Tecelagem e afins } & Fiadeira & $9(5,8 \%)$ & $1(2,5 \%)$ & - & - \\
\hline & & Tecedeira & $1(0,6 \%)$ & - & - & - \\
\hline & & Rendeira & $2(1,3 \%)$ & - & - & - \\
\hline & \multirow{2}{*}{ Couro, Peles e afins } & Curtidor & $1(0,6 \%)$ & - & - & - \\
\hline & & Seleiro & $2(1,3 \%)$ & - & - & - \\
\hline & Calçados & Sapateiro & $2(1,3 \%)$ & - & - & - \\
\hline & \multirow{3}{*}{ Vestuário } & Alfaiate & $2(1,3 \%)$ & - & - & - \\
\hline & & Costureira & $1(0,6 \%)$ & - & - & - \\
\hline & & Chapeleiro & $1(0,6 \%)$ & - & - & - \\
\hline & Alimentação & Padeiro & - & $1(2,5 \%)$ & - & - \\
\hline & \multicolumn{2}{|c|}{ Total do setor } & $29(18,6 \%)$ & $4(10,0 \%)$ & $1(5,0 \%)$ & - \\
\hline \multirow{2}{*}{ Igreja } & \multicolumn{2}{|c|}{ Clero secular } & $1(0,6 \%)$ & - & $1(5,0 \%)$ & - \\
\hline & \multicolumn{2}{|c|}{ Total do setor } & $1(0,6 \%)$ & - & $1(5,0 \%)$ & - \\
\hline \multirow{4}{*}{$\begin{array}{l}\text { Magistratura e } \\
\text { Empregos Civis }\end{array}$} & Tabeliães & Tabelião & $1(0,6 \%)$ & - & - & - \\
\hline & \multirow{2}{*}{$\begin{array}{c}\text { Escrivães, Oficiais de Justiça e } \\
\text { afins }\end{array}$} & Oficial de Justiça & $1(0,6 \%)$ & - & - & - \\
\hline & & Escrivão & $1(0,6 \%)$ & - & - & - \\
\hline & \multicolumn{2}{|c|}{ Total do setor } & $3(1,9 \%)$ & - & - & - \\
\hline \multirow{4}{*}{$\begin{array}{l}\text { Profissões } \\
\text { Liberais }\end{array}$} & \multirow{2}{*}{ Medicina, Cirurgia e afins } & Cirurgião & $1(0,6 \%)$ & - & - & - \\
\hline & & Boticário & $1(0,6 \%)$ & - & - & - \\
\hline & Ensino e afins & Professor & $1(0,6 \%)$ & - & - & - \\
\hline & \multicolumn{2}{|c|}{ Total do setor } & $3(1,9 \%)$ & - & $\cdot$ & - \\
\hline \multirow{5}{*}{ Comércio } & Casas de comércio e afins & Negociante & $20(12,8 \%)$ & $6(15,0 \%)$ & $1(5,0 \%)$ & - \\
\hline & Estalagens e afins & Taberneiro & $2(1,3 \%)$ & - & $1(5,0 \%)$ & - \\
\hline & Serviços de caixa e afins & Caixeiro & $1(0,6 \%)$ & - & - & - \\
\hline & Outras atividades de comércio & Negociante de bois & $1(0,6 \%)$ & - & - & - \\
\hline & \multicolumn{2}{|c|}{ Total do setor } & $24(15,4 \%)$ & $6(15,0 \%)$ & $2(10,0 \%)$ & - \\
\hline \multirow{2}{*}{ Transporte } & Transporte por via terrestre & Carreiro & $2(1,3 \%)$ & - & - & - \\
\hline & \multicolumn{2}{|c|}{ Total do setor } & $2(1,3 \%)$ & $\cdot$ & - & - \\
\hline \multirow{3}{*}{ Jornaleiros } & Jornaleiros & Jornaleiro & $1(0,6 \%)$ & - & - & - \\
\hline & \multicolumn{2}{|c|}{ Total do setor } & $1(0,6 \%)$ & - & - & - \\
\hline & \multicolumn{2}{|c|}{ Total geral } & $156(100,0 \%)$ & $40(100,0 \%)$ & $20(100,0 \%)$ & $7(100,0 \%)$ \\
\hline
\end{tabular}

* Exclusive 4 escravistas com ocupação múltipla e 25 escravistas com ocupação não declarada Fonte: APM, Lista Nominativa de Habitantes de Araxá, 1831-1832 
Tabela 8 - Distribuição das ocupações de escravistas por setores e ramos de atividade econômica e por faixas de tamanho dos plantéis (1831-1832)

\begin{tabular}{|c|c|c|c|c|c|c|}
\hline Setor & Ramo & Ocupação & 1 a 5 & 6 a 10 & 11 a 20 & Acima 20 \\
\hline \multirow{5}{*}{$\begin{array}{c}\text { Agricultura e } \\
\text { Manufatura Rural }\end{array}$} & Produção de açúcar & Engenheiro de cana & 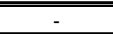 & - & $10(100,0 \%)$ & - \\
\hline & Cultivos não especificados & Lavrador & $89(63,6 \%)$ & $30(21,4 \%)$ & $15(10,7 \%)$ & $6(4,3 \%)$ \\
\hline & \multirow{2}{*}{ Pecuária } & Criador & $3(75,0 \%)$ & - & - & $1(25 \%)$ \\
\hline & & Boiadeiro & $1(110,0 \%)$ & - & - & - \\
\hline & \multicolumn{2}{|c|}{ Total do setor } & $93(63,7 \%)$ & $30(20,5 \%)$ & $16(11,0 \%)$ & $7(4,8 \%)$ \\
\hline \multirow{14}{*}{ Artesanato } & \multirow{2}{*}{ Metais } & Caldereiro & $1(100,0 \%)$ & - & - & - \\
\hline & & Ferreiro & $2(100,0 \%)$ & - & - & - \\
\hline & Madeiras & Carpinteiro ou carapina & $5(62,5 \%)$ & $2(25,0 \%)$ & $1(12,5 \%)$ & - \\
\hline & \multirow{3}{*}{ Fiação, Tecelagem e afins } & Fiadeira & $9(90,0 \%)$ & $1(10,0 \%)$ & - & - \\
\hline & & Tecedeira & $1(100,0 \%)$ & - & - & - \\
\hline & & Rendeira & $2(100,0 \%)$ & - & - & - \\
\hline & \multirow{2}{*}{ Couro, Peles e afins } & Curtidor & $1(100,0 \%)$ & - & - & - \\
\hline & & Seleiro & $2(100,0 \%)$ & - & - & - \\
\hline & Calçados & Sapateiro & $2(100,0 \%)$ & - & - & - \\
\hline & \multirow{3}{*}{ Vestuário } & Alfaiate & $2(100,0 \%)$ & - & - & - \\
\hline & & Costureira & $1(100,0 \%)$ & - & - & - \\
\hline & & Chapeleiro & $1(100,0 \%)$ & - & - & - \\
\hline & Alimentação & Padeiro & - & $1(100,0 \%)$ & - & - \\
\hline & \multicolumn{2}{|c|}{ Total do setor } & $29(85,3 \%)$ & $4(11,8 \%)$ & $1(2,9 \%)$ & - \\
\hline \multirow{3}{*}{ Igreja } & Clero secular & & $1(50,0 \%)$ & - & $1(50,0 \%)$ & - \\
\hline & \multicolumn{2}{|c|}{ Total do setor } & $1(50,0 \%)$ & - & $1(50,0 \%)$ & - \\
\hline & $\begin{array}{c}\text { Tabeliães } \\
\end{array}$ & Tabelião & $1(100,0 \%)$ & - & - & - \\
\hline \multirow{3}{*}{$\begin{array}{l}\text { Magistratura e } \\
\text { Empregos Civis }\end{array}$} & \multirow{2}{*}{$\begin{array}{c}\text { Escrivães, Oficiais de Justiça e } \\
\text { afins } \\
\end{array}$} & Oficial de Justiça & $1(100,0 \%)$ & - & - & - \\
\hline & & Escrivão & $1(100,0 \%)$ & - & - & - \\
\hline & \multicolumn{2}{|c|}{$\begin{array}{ll}\text { Total do setor } \\
\end{array}$} & $3(100,0 \%)$ & - & - & - \\
\hline \multirow{4}{*}{ Profissões Liberais } & \multirow{2}{*}{ Medicina, Cirurgia e afins } & Cirurgião & $1(100,0 \%)$ & - & - & - \\
\hline & & Boticário & $1(100,0 \%)$ & - & - & - \\
\hline & Ensino e afins & Professor & $1(100,0 \%)$ & - & - & - \\
\hline & \multicolumn{2}{|c|}{ Total do setor } & $3(100,0 \%)$ & - & - & - \\
\hline \multirow{5}{*}{ Comércio } & \multirow{2}{*}{$\begin{array}{l}\text { Casas de comércio e afins } \\
\text { Estalagens e afins }\end{array}$} & Negociante & $20(74,1 \%)$ & $6(22,2 \%)$ & $1(3,7 \%)$ & - \\
\hline & & Taberneiro & $2(66,7 \%)$ & - & $1(33,3 \%)$ & - \\
\hline & Serviços de caixa e afins & Caixeiro & $1(100,0 \%)$ & - & - & - \\
\hline & Outras atividades de comércio & Negociante de bois & $1(100,0 \%)$ & - & - & - \\
\hline & \multicolumn{2}{|c|}{ Total do setor } & $24(75,0 \%)$ & $6(18,8 \%)$ & $2(6,2 \%)$ & - \\
\hline \multirow{2}{*}{ Transporte } & Transporte por via terrestre & Carreiro & $2(100,0 \%)$ & - & - & - \\
\hline & \multicolumn{2}{|c|}{ Total do setor } & $2(100,0 \%)$ & - & - & - \\
\hline \multirow{2}{*}{ Jornaleiros } & Jornaleiros & Jornaleiro & $1(100,0 \%)$ & - & - & - \\
\hline & \multicolumn{2}{|c|}{ Total do setor } & $1(100,0 \%)$ & - & - & - \\
\hline
\end{tabular}

Soma-se $100 \%$ na horizontal em cada ocupação

* Exclusive 4 escravistas com ocupação múltipla e 25 escravistas com ocupação não declarada.

Fonte: APM, Lista Nominativa de Habitantes de Araxá, 1831-1832

De imediato, notamos também uma relação entre a quantidade de escravos possuídos e as atividades desenvolvidas: quanto maior o tamanho do plantel, menor a gama de atividades econômicas realizadas pelos proprietários, sendo a quase totalidade dos plantéis com mais de 10 escravos pertencentes a lavradores.

O setor comércio era o único, além da agricultura, com percentual considerável de participação em quase todas as faixas de tamanho de posse. Cerca de $15 \%$ dos possuidores de 1 a 5 e de 6 a 10 escravos 
tinham ocupação definida dentro desse setor, responsável por $10 \%$ dos grandes proprietários. O setor artesanato apareceu fracamente representado, apesar de $43,5 \%$ da população (cf. Tabela 6) estar empregada nesse setor, indicando que essa atividade encontrava-se disseminada, principalmente, em fogos onde não foi constatada a presença de cativos e, de maneira bastante relevante entre os pequenos proprietários, $18,6 \%$.

Considerando a participação de cada faixa de tamanho de plantel em cada setor, verificamos a importância das posses de 1 a 5 cativos em todos eles. Quase 64\% dos escravistas dedicados à agricultura e manufatura rural possuíam o máximo de 5 escravos, percentual elevado a $75 \%$ entre os comerciantes, e $85,3 \%$ para aqueles araxaenses empregados no artesanato.

Estatísticas relativas à quantidade de escravos pertencentes a proprietários nas distintas ocupações corroboram a importância das pequenas posses na economia araxaense. O cálculo da moda de escravos possuídos - por setores de atividades - mostra-nos, nos setores apresentados na Tabela 9, valor igual a 1 , enquanto as medianas foram de 2, 3 e 4, respectivamente nos setores comércio, agricultura e artesanato. Todos esses valores enquadravam-se entre os pequenos plantéis. Relativamente à média, podemos enfatizar o número médio de escravos do setor agricultura e manufatura rural, 6,2, bem maior que o atribuído aos demais setores, como reflexo da presença de grandes escravistas nessas atividades, apesar da predominância dos pequenos.

Tabela 9 - Indicadores estatísticos da distribuição da posse de escravos por setores de atividade econômica (1831-1832)

\begin{tabular}{lcccc}
\hline Setor & Média & Moda & Mediana & Gini \\
\hline Agricultura e Manufatura Rural & 6,2 & 1,0 & 3,0 & 0,538 \\
Artesanato & 3,2 & 1,0 & 4,0 & 0,413 \\
Comércio & 2,6 & 1,0 & 2,0 & 0,457 \\
Outros & 2,2 & 1,0 & 2,0 & 0,431 \\
\hline
\end{tabular}

Fonte: APM, Lista Nominativa de Habitantes de Araxá, 1831-1832

Apesar da presença de ampla maioria de escravistas de pequeno porte nas atividades produtivas de Araxá, os escravos distribuíam-se de maneira um pouco diferente dentro de cada atividade; dentro de 
cada FTP a presença de escravos foi bastante próxima à calculada para os senhores. Valores percentuais e absolutos podem ser visualizados na Tabela 10. Mesmo com 60,9\% dos escravos pertencentes a indivíduos descritos no setor artesanato em plantéis com até 5 indivíduos, 29,1\% estavam em plantéis com 6 a 10 e os $10 \%$ restantes em plantéis com 11 a 20 escravos, percentual superior aos 2,9\% de seus proprietários. Distinção levemente maior encontramos no comércio: $75 \%$ dos proprietários detinham $40,5 \%$ da escravaria. O índice de Gini entre os dois setores variava de 0,413 a 0,457. Porém, praticamente $27 \%$ dos cativos dos senhores envolvidos com a agricultura estavam em plantéis muito grandes (acima de 20 escravos), contra cerca de $24 \%$ em cada uma das demais FTP. O Gini para a agricultura foi de 0,538 - próximo ao calculado para o total de escravistas, 0,528, certamente influenciado por essa maioria de lavradores -, demonstrando maior concentração de cativos entre os proprietários do setor.

Tabela 10 - Distribuição dos escravos por setores de atividade econômica e faixas de tamanho dos plantéis (1831-1832)

\begin{tabular}{|c|c|c|c|c|c|c|c|c|c|c|}
\hline \multirow{2}{*}{ Setor } & \multicolumn{2}{|c|}{1 a 5} & \multicolumn{2}{|c|}{6 a 10} & \multicolumn{2}{|c|}{11 a 20} & \multicolumn{2}{|c|}{ Acima 20} & \multicolumn{2}{|c|}{ Total } \\
\hline & $\mathrm{N}^{\circ}$ & $\%$ & $\mathrm{~N}^{0}$ & $\%$ & $\mathrm{~N}^{\circ}$ & $\%$ & $\mathrm{~N}^{\circ}$ & $\%$ & $\mathrm{~N}^{0}$ & $\%$ \\
\hline Agricultura e Manufatura Rural & 221 & 24,3 & 226 & 24,8 & 219 & 24,0 & 245 & 26,9 & 911 & 100,0 \\
\hline Artesanato & 67 & 60,9 & 32 & 29,1 & 11 & 10,0 & - & - & 110 & 100,0 \\
\hline Igreja & 1 & 8,3 & - & - & 11 & 91,7 & - & - & 12 & 100,0 \\
\hline Magistratura e Empregos Civis & 6 & 100,0 & - & - & - & - & - & - & 6 & 100,0 \\
\hline Profissões Liberais & 6 & 100,0 & - & - & - & - & - & - & 6 & 100,0 \\
\hline Comércio & 47 & 40,5 & 47 & 40,5 & 22 & 19,0 & - & - & 116 & 100,0 \\
\hline Transporte & 2 & 100,0 & - & - & - & - & - & - & 2 & 100,0 \\
\hline Jornaleiros & 1 & 100,0 & - & - & - & - & - & - & 1 & 100,0 \\
\hline
\end{tabular}

* Exclusive 1313 escravos correspondentes aos chefes com ocupação múltipla ou não declarada Fonte: APM, Lista Nominativa de Habitantes de Araxá, 1831-1832

\section{Níveis e Distribuição da Riqueza}

$\mathrm{Na}$ Tabela 11 podemos visualizar a distribuição da riqueza entre os proprietários araxaenses, considerados por faixas de tamanho de riqueza ${ }^{13}$ entre $1816-20$ e $1886-88 .{ }^{14}$ Notamos, ao longo de todo o

${ }^{13}$ Quando mencionamos riqueza estamos tratando de riqueza bruta menos dívidas passivas, ou seja, riqueza líquida. Quando a análise se referir à riqueza bruta, esta será mencionada.

${ }^{14}$ É preciso notar, com respeito a 1888, a presença do inventário dos bens de Mizael Ferreira da Silva, figura esta excepcional, pois Mizael era possuidor de um patrimônio próximo a 110 mil libras (cf. Inventário de Mizael da Silva. 25/04/1888 - Arquivo FCCB, cx. 173), montante este correspondente a 75,2\% da riqueza bruta arrolada em 1886-1888. Em face disso, optamos por apresentar os dados para esse subperíodo de duas maneiras: incluindo o valor dos bens de Mizael (1888 A) e o excluindo (1888 B). 
lapso 1816-1820 a 1886-1888, uma forte concentração da riqueza inventariada, que tendeu a se acentuar em alguns momentos. A grande disparidade entre os indivíduos mais ricos e os menos aquinhoados deu-se em todos os anos considerados, e se revela, imediatamente, quando atentamos para a elevada concentração de riqueza em mãos de uns poucos.

Em 1816-20 e 1826-29 é reduzida a presença de montes acima de 1.000 libras. A partir de então é visível o surgimento de patrimônios individuais mais elevados em conjunto com um movimento de concentração da riqueza nestas faixas. A média dos patrimônios líquidos entre os mais abastados (a partir de 2001 libras) superou as 4.000 libras em 1816-1848 e 1856-1888.

Tabela 11 - Distribuição dos inventariados e da riqueza por faixas de riqueza (1816-1820 a $1886-1888)$

\begin{tabular}{|c|c|c|c|c|c|c|c|c|c|c|}
\hline \multirow{2}{*}{$\begin{array}{c}\text { Riqueza } \\
\text { (libras) }\end{array}$} & \multicolumn{2}{|c|}{$1816-1820$} & \multicolumn{2}{|c|}{$1826-1829$} & \multicolumn{2}{|c|}{$1836-1839$} & \multicolumn{2}{|c|}{$1846-1848$} & \multicolumn{2}{|c|}{$1856-1858$} \\
\hline & $\% \operatorname{lnv}$ & $\%$ Riq & $\% \operatorname{lnv}$ & $\%$ Riq & $\% \operatorname{lnv}$ & $\%$ Riq & $\% \operatorname{lnv}$ & $\%$ Riq & $\% \operatorname{lnv}$ & $\%$ Riq \\
\hline Até 100 & 17,4 & 1,9 & 37,8 & 7,4 & 5,0 & 0,2 & 28,9 & 1,5 & 4,4 & 0,1 \\
\hline 101 a 500 & 60,9 & 34,7 & 37,8 & 27,4 & 45,0 & 6,3 & 42,1 & 13,6 & 43,9 & 11,3 \\
\hline 501 a 1000 & 13,0 & 22,1 & 16,2 & 31,9 & 15,0 & 5,6 & 15,8 & 13,1 & 22,0 & 13,6 \\
\hline 1.001 a 2.000 & 4,3 & 10,6 & 8,1 & 33,3 & 10,0 & 8,7 & 2,6 & 3,7 & 12,2 & 15,8 \\
\hline Acima 2.000 & 4,3 & 30,7 & - & - & 25,0 & 79,1 & 10,5 & 68,1 & 17,1 & 59,3 \\
\hline Total & 100,0 & 100,0 & 100,0 & 100,0 & 100,0 & 100,0 & 100,0 & 100,0 & 100,0 & 100,0 \\
\hline \multirow{2}{*}{$\begin{array}{c}\text { Riqueza } \\
\text { (libras) }\end{array}$} & \multicolumn{2}{|c|}{$1866-1868$} & \multicolumn{2}{|c|}{$1876-1878$} & \multicolumn{2}{|c|}{ 1886-1888 A } & \multicolumn{2}{|c|}{$1886-1888 \mathrm{~B}$} & & \\
\hline & $\% \operatorname{lnv}$ & $\%$ Riq & $\% \operatorname{lnv}$ & $\%$ Riq & $\% \operatorname{lnv}$ & $\%$ Riq & $\% \operatorname{lnv}$ & $\%$ Riq & & \\
\hline Até 100 & 21,3 & 1,2 & 24,5 & 2,1 & 31,0 & 0,6 & 31,6 & 2,6 & & \\
\hline 101 a 500 & 36,1 & 8,6 & 37,7 & 14,8 & 41,4 & 3,4 & 42,1 & 14,6 & & \\
\hline 501 a 1.000 & 18,0 & 11,0 & 17,0 & 15,4 & 12,1 & 3,6 & 12,3 & 15,4 & & \\
\hline 1.001 a 2.000 & 9,8 & 12,0 & 13,2 & 24,9 & 8,6 & 4,5 & 8,8 & 19,3 & & \\
\hline Acima 2.000 & 14,8 & 67,2 & 7,5 & 42,7 & 6,9 & 87,8 & 5,3 & 48,0 & & \\
\hline Total & 100,0 & 100,0 & 100,0 & 100,0 & 100,0 & 100,0 & 100,0 & 100,0 & & \\
\hline
\end{tabular}

Fonte: FCCB, inventários post-mortem de Araxá, anos selecionados

Já em 1816-1820, temos um único documento (4,3\%), o inventário de Manoel Mendes dos Santos, respondendo por 30,7\% da riqueza total arrolada (cf. Inventário de Manoel dos Santos. 26/11/1816 Arquivo FCCB, cx. 12), valor pouco inferior à porcentagem da riqueza de outros $78,3 \%$ de inventariados, com bens avaliados em até 500 libras: $36,6 \%$. Desigualdade ainda maior é percebida, por exemplo, em 1866-68, quando $14,8 \%$ dos inventariados detinham mais de 6 vezes a riqueza de outros $57,4 \%$.

Embora no contexto do nosso trabalho os indivíduos nas faixas de riqueza inferiores possam ser considerados relativamente menos aqui- 
nhoados, é bastante provável se encontrarem em condições materiais mais favoráveis que uma outra parcela da população, dada a natureza dos documentos pesquisados (inventários post-mortem). Em outras palavras, podemos considerar haver uma concentração de riqueza ainda maior que a encontrada nos inventários.

Apesar de detectarmos um elevado percentual da riqueza descrita nos documentos nas mãos de poucos indivíduos, essa concentração é menor do que a verificada para outras regiões, em estudos também baseados em inventários post-mortem. A Tabela 12 mostra os valores disponíveis para outras localidades. Os dados referentes ao Rio de Janeiro, "o centro econômico e político do Sudeste brasileiro", nos anos 1820, 1840 e 1860, mostram que a faixa de riquezas pequenas (até 500 libras), mesmo conformando entre 36\% e 48\% dos inventários consultados por Fragoso (1998, p.311), concentrava não mais de 2,7\% do valor total dos patrimônios arrolados. Valores semelhantes foram apresentados por Renato Marcondes (1998, p.168) para a localidade vale-paraibana de Lorena (1830-1879), em meio a um movimento de rápido crescimento com base no cultivo do café: $50 \%$ do conjunto de inventários pesquisados possuíam ativos avaliados em até 500 libras, representando conjuntamente 2,1\% do somatório dos montes. A parte majoritária da riqueza local $(89,5 \%)$ encontrava-se na mão de pouco mais de $16 \%$ dos indivíduos considerados.

Tabela 12 - Distribuição dos inventariados e da riqueza bruta por faixas de riqueza bruta em diferentes localidades (século XIX)

\begin{tabular}{|c|c|c|c|c|c|c|c|c|c|c|c|c|}
\hline \multirow{3}{*}{$\begin{array}{c}\text { Riqueza } \\
\text { (libras) }\end{array}$} & \multirow{2}{*}{\multicolumn{2}{|c|}{$\begin{array}{c}\text { Mariana } \\
1850-1888\end{array}$}} & \multirow{2}{*}{\multicolumn{2}{|c|}{$\begin{array}{c}\text { Lorena } \\
1830-1879 \\
\end{array}$}} & \multirow{2}{*}{\multicolumn{2}{|c|}{$\begin{array}{l}\text { Mogi Mirim } \\
1831-1880 \\
\end{array}$}} & \multicolumn{6}{|c|}{ Rio de Janeiro } \\
\hline & & & & & & & \multicolumn{2}{|c|}{1820} & \multicolumn{2}{|c|}{1840} & \multicolumn{2}{|c|}{1860} \\
\hline & $\% \operatorname{lnv}$ & $\%$ Riq & $\%$ Inv & $\%$ Riq & $\% \operatorname{lnv}$ & $\%$ Riq & $\% \operatorname{lnv}$ & $\%$ Riq & $\% \operatorname{lnv}$ & $\%$ Riq & $\% \operatorname{lnv}$ & $\%$ Riq \\
\hline Até 500 & 55,2 & 10,3 & 50,0 & 2,1 & 57,2 & 8,1 & 48,3 & 2,7 & 46,7 & 2,6 & 35,9 & 1,5 \\
\hline 501 a 1.000 & 15,3 & 9,7 & \multirow{2}{*}{33,3} & \multirow{2}{*}{8,4} & \multirow{2}{*}{30,2} & \multirow{2}{*}{22,3} & 18,3 & 4,1 & 12,3 & 3,2 & 16,8 & 3,0 \\
\hline 1.001 a 2.000 & 13,8 & 6,5 & & & & & 8,3 & 4,0 & 15,0 & 7,7 & 7,6 & 3,0 \\
\hline Acima 2.000 & 15,7 & 63,5 & 16,7 & 89,5 & 12,6 & 69,6 & 25,1 & 89,2 & 26,0 & 85,5 & 39,6 & 92,5 \\
\hline Total & 100,0 & 100,0 & 100,0 & 100,0 & 100,0 & 100,0 & 100,0 & 100,0 & 100,0 & 100,0 & 99,9 & 100,0 \\
\hline
\end{tabular}

Fontes: Os dados de Mariana constam de Teixeira (2001), e são referentes ao monte-mor nas faixas de até 500 libras, de 500 a 999, 1000 a 1999 a acima de 2000 libras. Da mesma maneira os dados para Mogi Mirim constantes de Soares (2003) são faixas do monte bruto até 500, 500 a 1999 e acima de 2000 libras. Encontramos para Lorena em Marcondes (1998) as mesmas condições. E para o Rio os dados foram extraídos de Fragoso (1998), referentes também ao monte bruto, porém para as faixas de até 500, 501 a 1000, 1001 a 2000 e acima de 2000 libras.

Na também paulista Mogi Mirim, entre 1831-1880, as disparidades com respeito a Araxá parecem ser menores. Na mão de 57,2\% dos inventariados, Leonel Soares (2004, p.116) encontrou 8,1\% da rique- 
za arrolada. No outro extremo, 12,6\% dos inventariados, possuidores de mais de 2.000 libras cada um, detinham quase $70 \%$ da riqueza. Corroboram a semelhança dos valores as características econômicas da localidade. Como observa Soares,

A produção de gêneros de subsistência e a criação de animais constituíram, desde seus primórdios, a base econômica da população de Mogi Mirim, mantendo sua importância mesmo com a difusão da lavoura canavieira na região, já na última década do século XVIII. (Soares, 2004, pp.38-39)

Da mesma maneira, em Mariana, de acordo com os dados fornecidos por Heloísa Teixeira (2001, p.28), 55,2\% dos inventariados possuíam patrimônios de até 500 libras, correspondendo a 10,3\% da soma total dos montes; enquanto os mais abastados, $15,7 \%$, detinham $63,5 \%$ da riqueza descrita nos documentos. Os valores são referentes ao período 1850-1888. A esse tempo a economia de Mariana estava voltada à produção de subsistência e abastecimento de mercados inter e intraprovincial, destacando-se pela presença de atividades diversificadas. Fica visível, então, ser a riqueza melhor distribuída em locais onde predominavam atividades de subsistência, como Araxá, ainda que houvesse concentração. Em áreas com economias mais dinâmicas essa concentração era mais acentuada.

Apesar de próxima à distribuição encontrada em localidades como Mogi Mirim e Mariana, chama a atenção na distribuição araxaense a elevada quantidade de indivíduos a compor as faixas de riqueza de até 500 libras - em detrimento da faixa mais elevada -, comparativamente às demais localidades apresentadas na Tabela 12. Tal constatação parece indicar que o nível da riqueza em Araxá era inferior ao das demais localidades em questão.

As médias calculadas parecem apontar na mesma direção, por serem nitidamente inferiores às disponíveis para Mariana e Mogi Mirim, mostradas na Tabela 13. Enquanto para os inventariados araxaenses na faixa de até 500 libras a média da riqueza bruta encontrada foi 190,36 libras em 1856-1888, no período 1850-1888 nos inventários de Mariana a média alcançou 217,25 libras e, em Mogi Mirim (18311888), 199 libras. 
Comparação semelhante pode ser feita para a faixa intermediária, 500 a 2.000 libras: média igual a 977,34 libras em Araxá, 1382,44 libras em Mariana e 1.042 libras em Mogi Mirim.

Tabela 13 - Riqueza bruta média por faixas de riqueza bruta em diferentes localidades (século XIX)

\begin{tabular}{|c|c|c|c|c|c|}
\hline \multirow{2}{*}{$\begin{array}{c}\text { Riqueza } \\
\text { (libras) }\end{array}$} & \multirow{2}{*}{$\begin{array}{c}\text { Mariana } \\
1850-1888\end{array}$} & \multirow{2}{*}{$\begin{array}{l}\text { Mogi Mirim } \\
1831-1880\end{array}$} & \multicolumn{3}{|c|}{ Araxá } \\
\hline & & & $1816-1848$ & $1856-1888 \mathrm{~A}$ & $1856-1888 \mathrm{~B}$ \\
\hline Até 500 & 217.25 & 199,00 & 178,89 & 190,36 & 190,36 \\
\hline 500 a 2.000 & $1.039,40$ & $1.042,00$ & 852,93 & 977,34 & 977,34 \\
\hline Acima 2.000 & $4.721,30$ & $7.762,00$ & $3.962,27$ & $8.095,20$ & $4.481,41$ \\
\hline
\end{tabular}

Fontes: FCCB, inventários post-mortem de Araxá, anos selecionados. Os dados de Mariana constam de Teixeira (2001), e são referentes ao monte-mor nas faixas de até 500 libras, de 500 a 999, 1.000 a 1.999 a acima de 2.000 libras. Da mesma maneira os dados para Mogi Mirim constantes de Soares (2004) são faixas do monte bruto até 500, 500 a 1.999 e acima de 2.000 libras

Entre as maiores riquezas, essa constatação se repete quando comparamos as médias araxaenses e de Mogi Mirim. Verificamos, porém, um valor médio para a faixa mais elevada de patrimônios brutos em Araxá, excluindo-se Mizael, mais próximo ao encontrado para Mariana. Mas sabemos, dos comentários anteriores, que nessas localidades a maioria dos inventariados concentrava-se nas faixas mais reduzidas de riqueza, de modo que podemos reafirmar o reduzido nível de riqueza encontrado para a Araxá do século XIX.

A diferença de posses entre os mais e menos afortunados também pode ser vista através dos distintos tamanhos dos plantéis de escravos. Na Tabela 14 apresentamos a distribuição dos cativos de acordo com as faixas de riqueza, excluídos os não-escravistas. Como era de se esperar, a média de cativos por faixas de riqueza dos escravistas eleva-se na medida em que caminhamos para as faixas de patrimônio mais elevadas. A média de escravos pelas faixas de riqueza foi nitidamente crescente, com destaque para os plantéis de indivíduos mais aquinhoados, cujas médias, em geral, representaram um salto considerável com relação à faixa de riqueza anterior (1.001 a 2.000 libras). Em 1846-1848, por exemplo, foi igual a 22,5 a média de cativos por documento com bens avaliados acima de 2.000 libras mínimo igual a 13 , máximo igual a 38 . Por outro lado, calculamos para a faixa anterior média de 10 escravos por inventário. No final da década seguinte (1856-58), já após o término do tráfico intercontinental de cativos, a média foi calculada em 24,6 escravos para 
os mais abastados e 12,2 escravos para os componentes da faixa de riqueza imediatamente menor.

Para os anos 1816-1820, a média dos possuidores de 500 a 1.000 libras foi superior à encontrada para a faixa seguinte (1.001 a 2.000 libras) de riqueza. Porém, no todo, os dados apontam para o movimento identificado anteriormente, ou seja, faixa de riqueza e tamanho de plantel variam no mesmo sentido. ${ }^{15} \mathrm{O}$ único possuidor de mais de 2.000 libras, Manoel Mendes dos Santos, era dono de um plantel composto por 33 elementos, cujo valor representava $28,1 \%$ dos seus bens (cf. Inventário de Manoel dos Santos. 26/11/1816 Arquivo FCCB, cx. 12). A consideração é valida também em 188688 (considerados ou não os bens de Mizael), apesar de a elevação da média ser mais sutil entre as faixas de riqueza de até 2.000 libras.

Tabela 14 - Distribuição dos escravistas e dos escravos por faixas de riqueza dos escravistas (1816-1820 a 1886-1888)

\begin{tabular}{|c|c|c|c|c|c|c|c|c|c|}
\hline \multirow{2}{*}{$\begin{array}{c}\text { Riqueza } \\
\text { (libras) }\end{array}$} & \multicolumn{3}{|c|}{$1816-1820$} & \multicolumn{3}{|c|}{$1826-1829$} & \multicolumn{3}{|c|}{$1836-1839$} \\
\hline & $\% \operatorname{lnv}$ & $\%$ Escr & Média & $\% \operatorname{lnv}$ & $\%$ Escr & Média & $\% \ln v$ & $\%$ Escr & Média \\
\hline Até 100 & 10,5 & 2,8 & 1,5 & 26,7 & 6,7 & 1,63 & 5,0 & 0,4 & 1,0 \\
\hline 101 a 500 & 63,2 & 36,4 & 3,3 & 46,7 & 47,7 & 6,6 & 45,0 & 11,4 & 3,0 \\
\hline 501 a 1.000 & 15,8 & 24,3 & 8,7 & 16,7 & 25,9 & 10,0 & 15,0 & 6,3 & 5,0 \\
\hline 1.001 a 2.000 & 5,3 & 5,6 & 6,0 & 10,0 & 19,7 & 12,7 & 10,0 & 13,9 & 16,5 \\
\hline Acima 2.000 & 5,3 & 30,8 & 33,0 & - & - & - & 25,0 & 67,9 & 32,2 \\
\hline Total & 100,0 & 100,0 & 5,6 & 100,0 & 100,0 & 6,4 & 100,0 & 100,0 & 11,9 \\
\hline \multirow{2}{*}{$\begin{array}{c}\text { Riqueza } \\
\text { (libras) }\end{array}$} & \multicolumn{3}{|c|}{$1846-1848$} & \multicolumn{3}{|c|}{$1856-1858$} & \multicolumn{3}{|c|}{$1866-1868$} \\
\hline & $\% \operatorname{lnv}$ & $\%$ Escr & Média & $\% \operatorname{lnv}$ & $\%$ Escr & Média & $\% \operatorname{lnv}$ & $\%$ Escr & Média \\
\hline Até 100 & 13,8 & 6,7 & 3,8 & 2,8 & 0,3 & 1,0 & 10,4 & 1,7 & 1,6 \\
\hline 101 a 500 & 48,3 & 24,6 & 3,9 & 38,9 & 12,8 & 3,0 & 39,6 & 17,6 & 4,4 \\
\hline 501 a 1.000 & 20,7 & 24,1 & 9,0 & 25,0 & 17,8 & 6,7 & 20,8 & 14,9 & 7,0 \\
\hline 1.001 a 2.000 & 3,4 & 4,5 & 10,0 & 13,9 & 18,1 & 12,2 & 12,5 & 15,7 & 12,3 \\
\hline Acima 2.000 & 13,8 & 40,2 & 22,5 & 19,4 & 51,0 & 24,6 & 16,7 & 50,1 & 29,5 \\
\hline Total & 100,0 & 100,0 & 7,7 & 100,0 & 100,0 & 9,4 & 100,0 & 100,0 & 9,8 \\
\hline \multirow{2}{*}{$\begin{array}{c}\text { Riqueza } \\
\text { (libras) }\end{array}$} & \multicolumn{3}{|c|}{$1876-1878$} & \multicolumn{3}{|c|}{$1886-1888 \mathrm{~A}$} & \multicolumn{3}{|c|}{$1886-1888 \mathrm{~B}$} \\
\hline & $\% \operatorname{lnv}$ & $\%$ Escr & Média & $\% \operatorname{lnv}$ & $\%$ Escr & Média & $\% \operatorname{lnv}$ & $\%$ Escr & Média \\
\hline Até 100 & 2,8 & 1,8 & 3,0 & 22,6 & 9,3 & 2,0 & 23,3 & 11,8 & 2,0 \\
\hline 101 a 500 & 44,4 & 22,8 & 2,4 & 35,5 & 13,9 & 1,9 & 36,7 & 17,6 & 1,9 \\
\hline 501 a 1.000 & 22,2 & 19,2 & 4,0 & 16,1 & 12,6 & 3,8 & 16,7 & 16,0 & 3,8 \\
\hline 1.001 a 2.000 & 19,4 & 29,9 & 7,1 & 16,1 & 17,9 & 5,4 & 16,7 & 22,7 & 5,4 \\
\hline Acima 2.000 & 11,1 & 26,3 & 11,0 & 9,7 & 46,4 & 23,3 & 6,7 & 31,9 & 19,0 \\
\hline Total & 100,0 & 100,0 & 4,6 & 100,0 & 100,0 & 4,9 & 100,0 & 100,0 & 4,0 \\
\hline
\end{tabular}

Fonte: FCCB, inventários post-mortem de Araxá, anos selecionados

${ }^{15}$ De um modo geral as correlações entre o patrimônio líquido e o tamanho do plantel mostraram-se positivas e elevadas, denotando uma forte associação positiva entre as variáveis. As correlações variaram de 0,56 em 1876-78 a 0,93 em 1856-58. A correlação média do período 1816-1848 foi de 0,71, e na segunda metade do século a correlação média situou-se em 0,77. 
Com a distribuição inversa - riqueza por faixas de tamanho de plantel - podemos chegar a observações semelhantes quanto à relação entre a posse de cativos e o tamanho das fortunas, conforme exposto na Tabela 15. As médias são igualmente crescentes com o avanço nas faixas de tamanho de plantel. Em 1826-29, por exemplo, a média elevou-se de 217,20 libras para 923,68 libras por proprietário entre as faixas de tamanho de plantel extremas (até 5 e acima de 20 cativos); e a variação entre a menor e maior faixa de tamanho de plantel em 1866-68 foi de 249,27 libras para 5.644,22 libras.

É importante notar também que os patrimônios dos proprietários de cativos eram superiores à dos não proprietários na totalidade dos subperíodos selecionados, sendo os escravistas concentradores da riqueza. ${ }^{16}$ Característica marcante dos não proprietários de escravos foi a reduzida faixa de valor dos patrimônios que possuíam. Essa situação é mais evidente na primeira metade do século XIX quando as posses dos indivíduos nessas condições não passaram das 493 libras, ou seja, mantiveram-se nas pequenas faixas de riqueza. ${ }^{17}$

16 Entre 1816-20 e 1876-78, os escravos eram os bens mais representativos no total da riqueza dos araxaenses. Porém, após o pico de participação na composição da riqueza atingido em fins da década de 1850, houve queda progressiva da participação do ativo escravo na riqueza, como reflexo da somatória de eventos atuantes contra a instituição da escravidão. Os escravos que chegaram a representar $48,6 \%$ dos bens inventariados em 1856-58, foram sendo paulatinamente substituídos pelos bens imóveis, que em 1886 -1888 responderam por $53,8 \%$ da riqueza (excluindo-se Mizael).

17 À exceção de Mariana Rodrigues, cujos bens avaliados em 521.74 libras no ano de 1826 não incluíam um escravo sequer; no entanto, vale notar que Mariana era preta forra "natural da África" (cf. Inventário de Mariana Rodrigues. 26/06/1826 - Arquivo FCCB, cx.22) 
Tabela 15 - Distribuição dos inventariados e da riqueza por faixas de tamanho dos plantéis (1816-1820 a 1886-1888)

\begin{tabular}{|c|c|c|c|c|c|c|c|c|c|}
\hline \multirow{2}{*}{ FTP } & \multicolumn{3}{|c|}{$1816-1820$} & \multicolumn{3}{|c|}{$1826-1829$} & \multicolumn{3}{|c|}{$1836-1839$} \\
\hline & $\% \operatorname{lnv}$ & $\%$ Riq & Média & $\% \operatorname{lnv}$ & $\%$ Riq & Média & $\% \ln v$ & $\%$ Riq & Média \\
\hline 0 & 17,4 & 9,2 & 247,95 & 18,9 & 7,1 & 115,74 & 50,0 & 7,0 & 221,70 \\
\hline 1 a 5 & 56,5 & 30,4 & 251,31 & 48,6 & 34,2 & 217,20 & 15,0 & 5,2 & 551,20 \\
\hline 6 a 10 & 17,4 & 22,6 & 608,29 & 18,9 & 30,5 & 498,73 & 15,0 & 15,0 & $1.595,70$ \\
\hline 11 a 20 & 4,3 & 7,1 & 763,81 & 8,1 & 12,1 & 460,74 & 20,0 & 72,8 & $5.798,01$ \\
\hline Acima 20 & 4,3 & 30,7 & $3.300,47$ & 5,4 & 16,1 & 923,68 & - & - & - \\
\hline Total & 100,0 & 100,0 & 467,66 & 100,0 & 100,0 & 309,20 & 100,0 & 100,0 & $1.592,49$ \\
\hline \multirow{2}{*}{ FTP } & \multicolumn{3}{|c|}{$1846-1848$} & \multicolumn{3}{|c|}{$1856-1858$} & \multicolumn{3}{|c|}{$1866-1868$} \\
\hline & $\% \operatorname{lnv}$ & $\%$ Riq & Média & $\% \operatorname{lnv}$ & $\%$ Riq & Média & $\% \ln v$ & $\%$ Riq & Média \\
\hline 0 & 23,7 & 1,5 & 47,60 & 12,2 & 1,4 & 122,45 & 21,3 & 6,4 & 334,09 \\
\hline 1 a 5 & 42,1 & 13,5 & 238,00 & 43,9 & 15,9 & 388,73 & 34,4 & 7,8 & 249,27 \\
\hline 6 a 10 & 21,1 & 13,6 & 481,54 & 17,1 & 9,9 & 623,72 & 24,6 & 16,2 & 726,55 \\
\hline 11 a 20 & 5,3 & 44,1 & $6.237,72$ & 17,1 & 34,6 & $2.169,04$ & 8,2 & 10,9 & $1.469,32$ \\
\hline Acima 20 & 7,9 & 27,3 & $2.577,74$ & 9,8 & 38,1 & $4.182,17$ & 11,5 & 58,7 & $5.644,72$ \\
\hline Total & 100,0 & 100,0 & 744,67 & 100,0 & 100,0 & $1.070,42$ & 100,0 & 100,0 & $1.103,86$ \\
\hline \multirow{2}{*}{ FTP } & \multicolumn{3}{|c|}{$1876-1878$} & \multicolumn{3}{|c|}{ 1886-1888 A } & \multicolumn{3}{|c|}{ 1886-1888 B } \\
\hline & $\% \operatorname{lnv}$ & $\%$ Riq & Média & $\% \operatorname{lnv}$ & $\%$ Riq & Média & $\% \operatorname{lnv}$ & $\%$ Riq & Média \\
\hline 0 & 32,1 & 6,9 & 150,45 & 46,6 & 9,2 & 487,24 & 47,4 & 39,1 & 487,2 \\
\hline 1 a 5 & 47,2 & 27,0 & 397,56 & 41,4 & 5,6 & 331,93 & 42,1 & 23,7 & 331,9 \\
\hline 6 a 10 & 17,0 & 53,4 & $2.183,66$ & 6,9 & 4,1 & $1.462,29$ & 7,0 & 17,4 & $1.462,3$ \\
\hline 11 a 20 & 3,8 & 12,7 & $2.335,08$ & 1,7 & 1,2 & $1.766,92$ & 1,8 & 5,3 & $1.766,9$ \\
\hline Acima 20 & - & - & - & 3,4 & 79,9 & $57.098,05$ & 1,8 & 14,6 & $4.914,8$ \\
\hline Total & 100,0 & 100,0 & 694,71 & 100,0 & 100,0 & $2.464,80$ & 100,0 & 100,0 & 590,4 \\
\hline
\end{tabular}

Fonte: FCCB, inventários post-mortem de Araxá, anos selecionados

Já na segunda metade do século, 2 indivíduos (3,2\% dos não-escravistas) estavam entre os mais abastados, apesar de não serem senhores de cativos. No entanto, Anna Sabina dos Santos, possuidora de 8.373,58 libras, teve seus bens arrolados em junho de 1888, ou seja, após a abolição. Assim, entre os mais aquinhoados não escravistas, apenas Pedro Amado de São Paulo, cujo inventário de 1868 descrevia riqueza avaliada em 2.888,13 libras, tinha a possibilidade de ter escravos entre seus bens. Outros 6,5\% dos inventariados do período possuíam entre 500 e 1.000 libras, estando igualmente na condição de não proprietários de cativos. Ainda assim, é clara a predominância de indivíduos nessa condição entre os detentores de até 500 libras.

Notamos também elevação, a 29,2\%, no percentual de inventários nos quais não foram descritos plantéis no período 1856-1888, e mesmo se eliminamos os documentos abertos a partir de maio de 
1888, esse percentual ainda é considerável, 26,6\%, refletindo todo o processo de término da escravidão no Brasil, institucionalmente representado por uma série de medidas legais - gradual processo de transição do trabalho escravo para o livre - como o fechamento do tráfico internacional em 1850 (lei Eusébio de Queiroz), Decreto $\mathrm{n}^{\mathrm{o}} 1695$ de 1869, que proibia a separação por venda das famílias escravas, Lei de Ventre Livre (1871), Fundo de Emancipação (1872), impostos proibitivos, Lei dos Sexagenários (1885) e, por fim, pela Abolição (1888). ${ }^{18}$

\section{Considerações Finais}

Seria ocioso reproduzir, nestas considerações finais, todo o elenco de inferências realizado ao longo do texto em que procuramos estudar a localidade mineira de Araxá no período 1816-1888, considerando, em especial, aspectos dos senhores de escravos locais, tais como características demográficas, atividades produtivas, posse de cativos e acúmulo de riqueza.

Mas vale observar que como características dos proprietários de cativos podemos citar a predominância dos homens casados, possuidores de plantéis predominantemente pequenos e médios. Cerca de $37,6 \%$ dos fogos araxaenses em 1831-32 possuíam cativos, que representavam 30,8\% da população nesses anos.

Entre as ocupações declaradas para livres nos censos destacaramse as atividades do setor agricultura e manufatura rural, estando a maioria dos araxaenses ocupados na lavoura e eventualmente na criação, visto que estas atividades caminhavam juntas. Mostraram-se importantes também as atividades ligadas ao artesanato, enquanto o núcleo urbano apresentou uma diversificada gama de atividades.

\footnotetext{
${ }^{18}$ Sete $(16,7 \%)$ dos 42 inventários componentes da amostra de 1886-1888 foram abertos após a abolição, ou seja, sem a possibilidade de arrolarem escravos. Esses documentos foram utilizados na análise do nível da riqueza. Ainda que o término da escravidão tenha ocorrido gradativamente, com muitos escravistas deixando de ampliar ou até mesmo repor seus plantéis, vale observar a possibilidade de que os valores utilizados possam estar defasados, devido à perda de cativos por algum eventual escravista em 13 de maio de 1888.
} 
No setor agricultura identificamos um percentual de cerca de $58 \%$ dos escravistas e $78 \%$ de escravos que, a sua vez, encontravam-se distribuídos de maneira relativamente equilibrada entre as FTP (24\% a cerca de $27 \%$ em cada faixa).

Notamos também, ao longo de todo período 1816-1820 e 1886-1888, uma forte concentração da riqueza inventariada, sendo percebida na grande quantidade de riqueza na mão de poucos indivíduos. A riqueza estava intimamente ligada à concentração de cativos: a riqueza média dos proprietários de cativos era superior à dos não proprietários. Ao longo do século houve um aumento do nível da riqueza acumulada em Araxá, porém essa elevação não foi generalizada, foi puxada pelas faixas mais elevadas da distribuição: $25,4 \%$ dos inventariados na primeira metade do século possuíam não mais de 100 libras, percentual que variou para cerca de $21,5 \%$ no período seguinte.

\section{Anexo 1}

Desde o início de sua formação e durante todo o século XIX, a unidade territorial e administrativa de Araxá passou por várias modificações. Ao longo desse período, verificamos o surgimento de diversas localidades dentro do território araxaense que, em alguns casos, vieram a se desmembrar de Araxá, ocorrência bastante comum à época. Ao fim do século XIX as localidades de Dores de Santa Juliana (atual Santa Juliana), Nossa Senhora da Conceição (Perdizes), São Pedro de Alcântara (Ibiá) e Santo Antônio da Pratinha (Pratinha) ainda permaneciam sob a jurisdição de Araxá. É a região, grosso modo, compreendida por Araxá e estas quatro localidades, a que nos referimos quando mencionamos Araxá. Deste modo, procuramos estabelecer um espaço que se mantivesse ao longo de todo o período estudado, 1776 a 1898, possibilitando a comparação de informações ao longo do tempo. Além de elementos físicos e histórico-administrativos, o espaço delimitado caracteriza-se pela semelhança em seus aspectos econômicos. A Figura 1 mostra a Araxá estudada, dentro do espaço mineiro. 


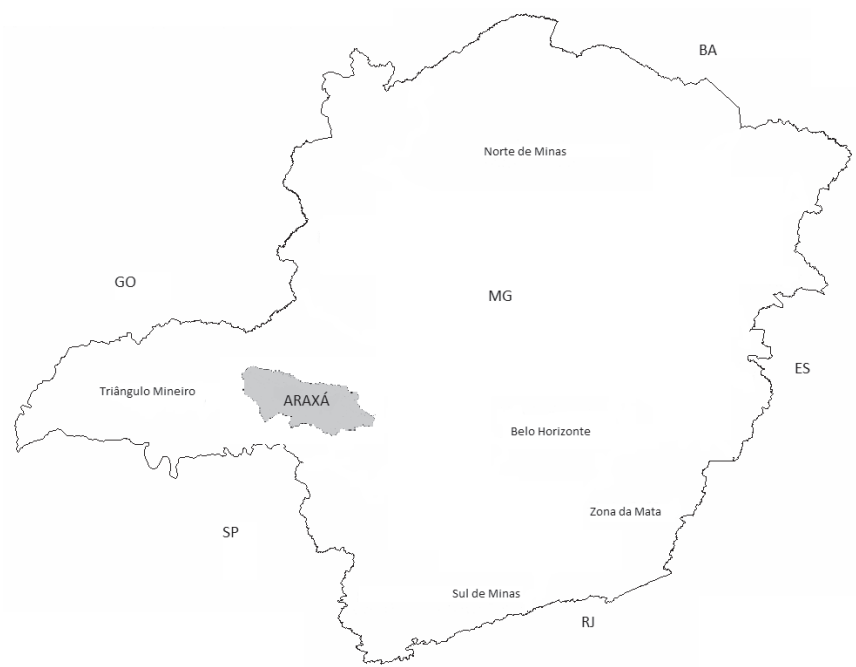

Figura 1 - Aproximação do território estudado (Projeção sobre mapa atual)

\section{Referências}

\section{Fontes primárias}

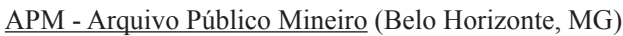

Mapas de população (MP), caixa 7 - Censo da Província de Minas Gerais de 1834

Sessão Provincial, Presidência da Província (SPPP), SPPP1/10, caixa 2 - Listas Nominativas de Habitantes - Distrito Paroquial de São Domingos do Araxá (1832) e Distrito da Capela de São Pedro de Alcântara, Termo do Araxá (1831), da Comarca da Vila de Paracatu do Príncipe.

FCCB - Fundação Cultural Calmon Barreto (Araxá, MG)

Arquivo Fórum, caixas 1 a 200 - Inventários post-mortem

AFAG (Arquivo Família Aguiar), caixas 1 e 2 - Documentos de Mizael Ferreira da Silva

\section{Fontes secundárias}

BACELLAR, C. de A. P. Viver e sobreviver em uma vila colonial: Sorocaba, séculos XVIII e XIX. São Paulo: Annablume/Fapesp, 2001.

BARBOSA, W. de A. Dicionário Histórico-Geográfico de Minas Gerais. Belo Horizonte: Itatiaia, 1995.

FRAGOSO, J. L. R. Homens de grossa aventura: acumulação e hierarquia na praça mercantil do Rio de Janeiro (1790-1830). Rio de Janeiro: Civilização Brasileira, 1998. $2^{\text {a }}$ Edição revista.

LIBBY, D. C. Transformação e trabalho em uma economia escravista: Minas Gerais no século XIX São Paulo: Brasiliense, 1988. 
LIMA, G. T. N. L. Das águas passadas à terra do sol; ensaio sobre a história de Araxá. Belo Horizonte: BDMG Cultural,1999.

LUNA, F. V. São Paulo; população, atividades e posse de escravos em vinte e cinco localidades (17771829). Estudos Econômicos 28 (1): 99-169, jan. /mar.1998.

MARCÍLIO, M. L. Caiçara, terra e população: estudo de demografia histórica e da história social de Ubatuba. São Paulo: Edusp, 2006.

MARCONDES, R. L. A arte de acumular na economia cafeeira: Vale do Paraíba, século XIX. Lorena: Editora Stiliano, 1998.

MARTINS, A. de A. \& MARQUES, J de O. (org.) Almanak administrativo, civil e industrial da Província de Minas Gerais para o ano de 1865. Ouro Preto: Typographia de Minas Gerais. 1864.

MATOS, R. J. da C. Corografia histórica da província de Minas Gerais - 1837. Belo Horizonte: Imprensa Oficial, 1979.

MELlO, Z. M. C. de. Metamorfose da riqueza: São Paulo, 1845-1888. São Paulo: Hucitec/Prefeitura do Município de São Paulo/ Secretaria Municipal de Cultura,1990.

MOTTA, J. F. Velhos no cativeiro: posse e comercialização de escravos idosos. In: XVI Encontro Nacional de Estudos Populacionais, 2008, Caxambu. Anais do XVI Encontro Nacional de Estudos Populacionais. Caxambu: Associação Brasileira de Estudos Populacionais, 2008.

MOTTA, J. F., NOZOE, N. \& COSTA, I. del N. da. Às vésperas da abolição - um estudo sobre a estrutura da posse de escravos em São Cristóvão (RJ), 1870. Estudos Econômicos 34: 157-213, jan. /mar. 2004.

PAIVA, C. A. \& KLEIN, H. S. Escravos e livres nas Minas Gerais do século XIX: Campanha em 1831. Estudos Econômicos 22 (1): 129-151, jan./abr. 1992.

PAIVA, C. A. \& LIBBY, D. C. Caminhos alternativos: escravidão e reprodução em Minas Gerais no século XIX. Estudos Econômicos 25 (2): 203-233, maio/ago. 1995.

PAIVA, C. A. População e economia nas Minas Gerais do século XIX. Tese de doutoramento. FFLCH/ USP, 1996.

PAIVA, C. A. \& MARTINS, R. B. Um estudo crítico do recenseamento de 1872. Belo Horizonte: CEDEPLAR, 1983.

SAMPAIO, A. C. J. de. Magé na crise do escravismo - sistema agrário e evolução econômica na produção de alimentos, 1850 - 1888. Dissertação de Mestrado. Niterói: UFF, 1994. (mimeografado).

SOARES, L. de O. No caminho dos goiases: formação e desenvolvimento da economia escravista na Mogi Mirim do século XIX. Dissertação de Mestrado. São Paulo: FFLCH/USP, 2003.

SILVA, J. J. da S. Tratado de geografia descritiva especial da província de Minas Gerais. Belo Horizonte: Fundação João Pinheiro, 1997.

TEIXEIRA, H. M. Reprodução e Famílias Escravas de Mariana 1850-1888. Dissertação de Mestrado. São Paulo: FFLCH/USP, 2001.

TEIXEIRA, P. E. O outro lado da família brasileira. Campinas, SP: Editora da Unicamp, 2004.

VERSIANI, F. R. \& VERGOLINO, J. R. O. Preços de Escravos em Pernambuco no século XIX. Brasília: UNB, 2002 (Texto para discussão $n^{\circ}$ 252) 